\title{
9. CRETACEOUS REDEPOSITED BENTHIC FORAMINIFERS FROM DEEP SEA DRILLING PROJECT SITE 585 IN THE EAST MARIANA BASIN, WESTERN EQUATORIAL PACIFIC, AND IMPLICATIONS FOR THE GEOLOGIC HISTORY OF THE REGION1
}

\author{
William V. Sliter, U.S. Geological Survey²
}

\begin{abstract}
Cretaceous benthic foraminifers from Site 585 in the East Mariana Basin, western Pacific Ocean, provide an environmental and tectonic history of the Basin and the surrounding seamounts. Age diagnostic species (from a fauna of 155 benthic species identified) range from late Aptian to Maestrichtian in age. Displaced species in sediments derived from the tops and flanks of nearby seamounts were deposited sporadically on the Basin floor well below the carbonate compensation depth (CCD) at abyssal depths of 5000 to $6000 \mathrm{~m}$. These depths, characterized by an indigenous assemblage of benthic foraminifers, recrystallized radiolarians, fish debris, and sponge spicules, existed in the Mariana Basin from late Aptian to the present. Early Albian and older edifice-building volcanism had reached the photic zone with associated shallow-water bank or reef environments. By middle Albian, the dominant source areas subsided to outer-neritic to upper-bathyal depths. Major volcanic activity ceased and fine-grained sediments were deposited by distal turbidites, although intermittent volcanism and the influx of rare neritic material continued until the late Albian. By the Cenomanian to Turonian, upper- to middle-bathyal depths were reached by the dominant source areas, and the sediments recovered from this interval include organic carbon-rich layers. Rare benthic foraminifers from the Coniacian-Santonian interval indicate a continuation of dominantly middle-bathyal source areas. A change in sedimentation during the Campanian-Maestrichtian from older zeolitic claystone to abundant chert in the Campanian, and nannofossil chalk and claystone in the Maestrichtian resulted from migration of the site beneath the equatorial productive zone due to northwestward plate motion. The appearance of rare middle-neritic and upper-bathyal species in the Maestrichtian interval associated with volcanogenic debris gives evidence of the remobilization and downslope transport of pelagic deposits due to thermally induced uplift.

Episodic redeposition of shallow-water material during the Aptian-Albian was produced by edifice-building volcanism perhaps combined with eustatic lowering of sea level. The Cenomanian-Turonian pulse coincided with a low global sea-level stand as does the transported material during the Coniacian-Santonian. The Maestrichtian pulse was caused by renewed midplate volcanism that extended over a large area of the central Pacific.
\end{abstract}

\section{INTRODUCTION}

Cretaceous foraminifers of late Aptian to Maestrichtian age were recovered from Site 585 in the East Mariana Basin, western equatorial Pacific (Fig. 1). The Mariana Basin is a relatively featureless deep basin enclosed by the $3000-\mathrm{fm}$ contour line $(5490 \mathrm{~m})$. Several areas lie deeper than the $3200-\mathrm{fm}$ line $(5870 \mathrm{~m})$, including the East Mariana Basin area of Site 585. The Basin is bordered on the north by the Magellan Seamounts, on the south by a group of seamounts that include Ita Maitai Guyot, farther to the south by seamounts of the Caroline Islands, and still farther removed to the west by a group of large seamounts on the edge of the Mariana Trench.

Two single-bit holes were drilled at a water depth of $6109 \mathrm{~m}\left(13^{\circ} 29.00^{\prime} \mathrm{N} ; 156^{\circ} 48.91^{\prime} \mathrm{E}\right)$ in an attempt to penetrate Jurassic strata underlain by 150 - to $160-\mathrm{m}$.y.-old lithosphere inferred from magnetic anomaly patterns. Hole 585 penetrated $763.7 \mathrm{~m}$ to upper Aptian sediments, and 55 cores were taken with a core recovery of $32 \%$ before operations were terminated because of a wedged core barrel. A second attempt was made at Hole 585A where continuous core recovery began at $772 \mathrm{~m}$ with

\footnotetext{
${ }^{1}$ Moberly, R., Schlanger, S. O., et al., Init. Repts. DSDP, 89: Washington (U.S. Govt. Printing Office)

2 Address: U.S. Geological Survey, 345 Middlefield Rd., Menlo Park, CA 94025.
}

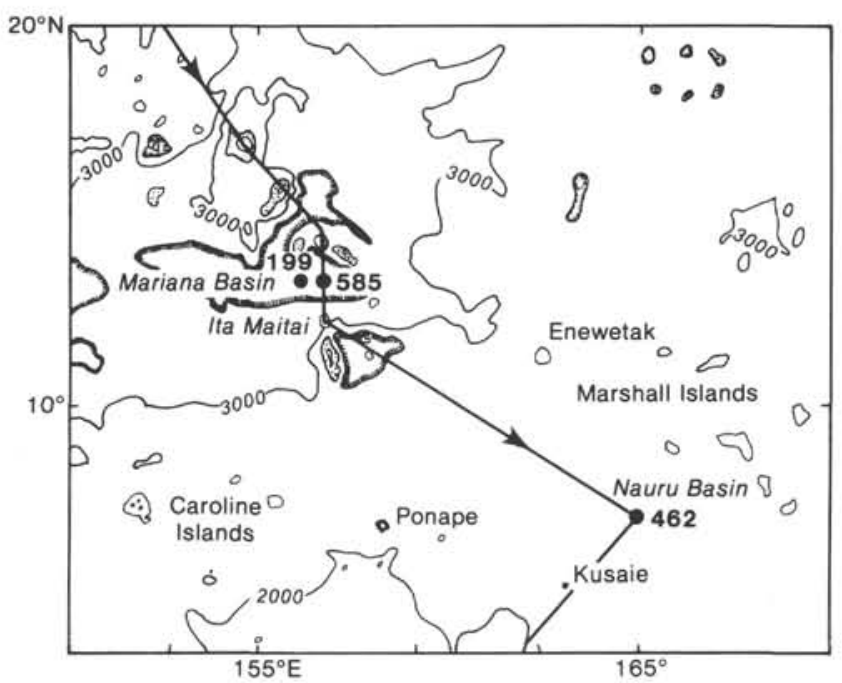

Figure 1. Location of Site 585 drilled in the East Mariana Basin with the positions of DSDP Site 199, Ita Maitai Guyot, and Site 462 in the Nauru Basin. (Contours in fathoms.)

Core 11 and bottomed at $892.8 \mathrm{~m}$ in upper Aptian sediments for a total of 22 cores at a recovery rate of $48.6 \%$. Operations at Hole 585A were terminated because of bit failure.

The Cretaceous sedimentary sequence consists of a thick section of upper Aptian to middle Albian coarse 
volcaniclastic gravity flows including coarse sandstone and breccia with shallow-water biogenic components and ooids (Fig. 2). This is overlain by nannofossil-bearing claystone, radiolarian-bearing limestone, and siltstone of middle Albian to Cenomanian age with common parallel laminations and several graded units. Immediately upsection is upper Cenomanian to Coniacian claystone with variable concentrations of recrystallized radiolarians and several layers of organic debris. The overlying Campanian sequence consists of a lower unit of moderately bioturbated, massive-appearing dark claystone and an upper unit of chert and zeolite-bearing claystone. Textural characteristics and fabrics suggest that the chert formed by silicification of graded carbonate grainstone. Stratigraphically above is an upper Campanian to Maestrichtian sequence of dark zeolite-bearing claystone, nannofossil claystone, and chert. Grading is apparent in many of the units. The final Mesozoic section consists of Maestrichtian nannofossil chalk with abundant chert and silicified limestone.

Cretaceous foraminifers recovered from Site 585 consist of four groups: (1) sporadic occurrences of mostly poorly preserved planktonic foraminifers associated with redeposited sediment; (2) autochthonous abyssal benthic species, characteristic of water depths between 5000 and $6000 \mathrm{~m}$ and well below the calcite compensation depth (CCD); (3) displaced, largely calcareous bathyal and abyssal benthic species from above the CCD; and (4) displaced neritic and shallow-water species. Reported here is the displaced assemblage derived from neritic, bathyal, and abyssal environments above the CCD. Not included here are the larger neritic species or those with complex wall structure. A total of 155 species are identified (see Appendix A), and the majority are illustrated.

The bathyal and abyssal faunas from Site 585 provide a rare glimpse of Cretaceous deep-water species that inhabited environments at or just above the CCD. These faunas were remobilized and deposited at abyssal depths below the CCD. The sporadic influx of sediments that originated from the surrounding seamounts was deposited by coarse debris flows and turbidites. Consequently, the benthic foraminifers recovered primarily from the coarser basal units of redeposited sedimentary deposits also are found sporadically, are hydrodynamically sorted to a size range of 45 to $149 \mu \mathrm{m}$, and, in general, are poorly preserved. The majority of samples examined were either barren of foraminifers or contained very rare, poorly preserved, and undiagnostic displaced specimens (Appendix B). The faunas are of particular interest for they (1) record the taxonomic content of the deep-sea assemblages, (2) provide a geologic history of the surrounding volcanic edifices, and (3) aid in the interpretation of regional redeposition events.

\section{BIOSTRATIGRAPHY}

The presence of age-diagnostic benthic species substantiates the ages derived from pelagic microfossils (Bergen; Premoli Silva; and Schaaf, this volume). Little reworking of diagnostic benthic species is evident despite the obvious sediment displacement and reworking of pelagic microfossils. The low abundances and hydrologic characteristics of the typically longer-ranging benthic species probably accounts for the lack of obvious reworking compared to the planktonic faunas. Although the age of the abyssal host sediment is unknown, the scarcity of reworking suggests that the timing of sediment displacement was largely contemporaneous with the original deposition. Still, it must be remembered that the sporadic recovery of foraminifers is linked to a series of resedimentation events that show a regular progression of biostratigraphic ages from Aptian to Maestrichtian. The 32 samples reported here represent a small percentage of the samples examined from both holes at Site 585 (Appendix B). Thus the ages reported, as those from the other microfossil groups, represent "local" events that may differ from the actual age of deposition. The ages derived from the displaced benthic foraminifers, therefore, must be considered "maximum" ages.

\section{Aptian}

Cores 585-55 to 585-52 were questionably assigned to the Aptian, primarily on the basis of radiolarians (Schaaf, this volume). A single sample from Core 58554 contains rare specimens of Lenticulina gaultina and Valvulineria loetterle, which supports that age determination. Lenticulina gaultina first appears in the early Aptian whereas Valvulineria loetterle has a Barremian to Turonian range (Table 1, Fig. 3; see Plates 1-15 and Appendix A for species identifications). Cores 585A-16 to $585 \mathrm{~A}-11$ also fall within the Aptian interval. Supporting the age assignment are the presence of Epistomina reticulata with a known range of middle Aptian to late Albian, Osangularia schloenbachi with a late Aptian to middle Albian range, and Lenticulina gaultina (Table 2).

\section{Albian}

Samples from Cores 585-51 to 585-39 are Albian in age. Of particular interest is the presence of Spiroplectinata annectens, Gavelinella rudis, and $G$. barremiana bizouardae, all of which are confined to the Albian. Additional species typical of Albian assemblages include Gaudryina reicheli, G. dividens, Textularia washitensis, and Praebulimina nannina; the first appearance of $\mathrm{Ga}$ velinella cenomanica also supports an Albian age. No allochthonous benthic foraminifers were recovered from the Albian interval of Hole 585A.

\section{Cenomanian-Turonian}

Dating of the Cenomanian-Turonian interval at Site 585 is difficult because of the sporadic occurrence and poor preservation of the pelagic microfossils. Likewise, the recovery of allochthonous benthic foraminifers is very patchy within this interval. The Cenomanian in Hole 585 is represented by samples from Sections 3 and 4 of Core 585-32. Species restricted to this interval include Cassidella tegulata, Orithostella pazdroae, Gavelinella belorussica, Pseudospiroplectinata compressiuscula, and Spiroplectinata complanata. The interval is marked by the last appearances of Gyroidinoides infracretacea, $G$. subglobosa, Dorothia conula, Guadryina cushmani, Praebulimina nannina, Pleurostomella obtusa, and Vaginulina recta. First appearances include Praebulimina reus- 


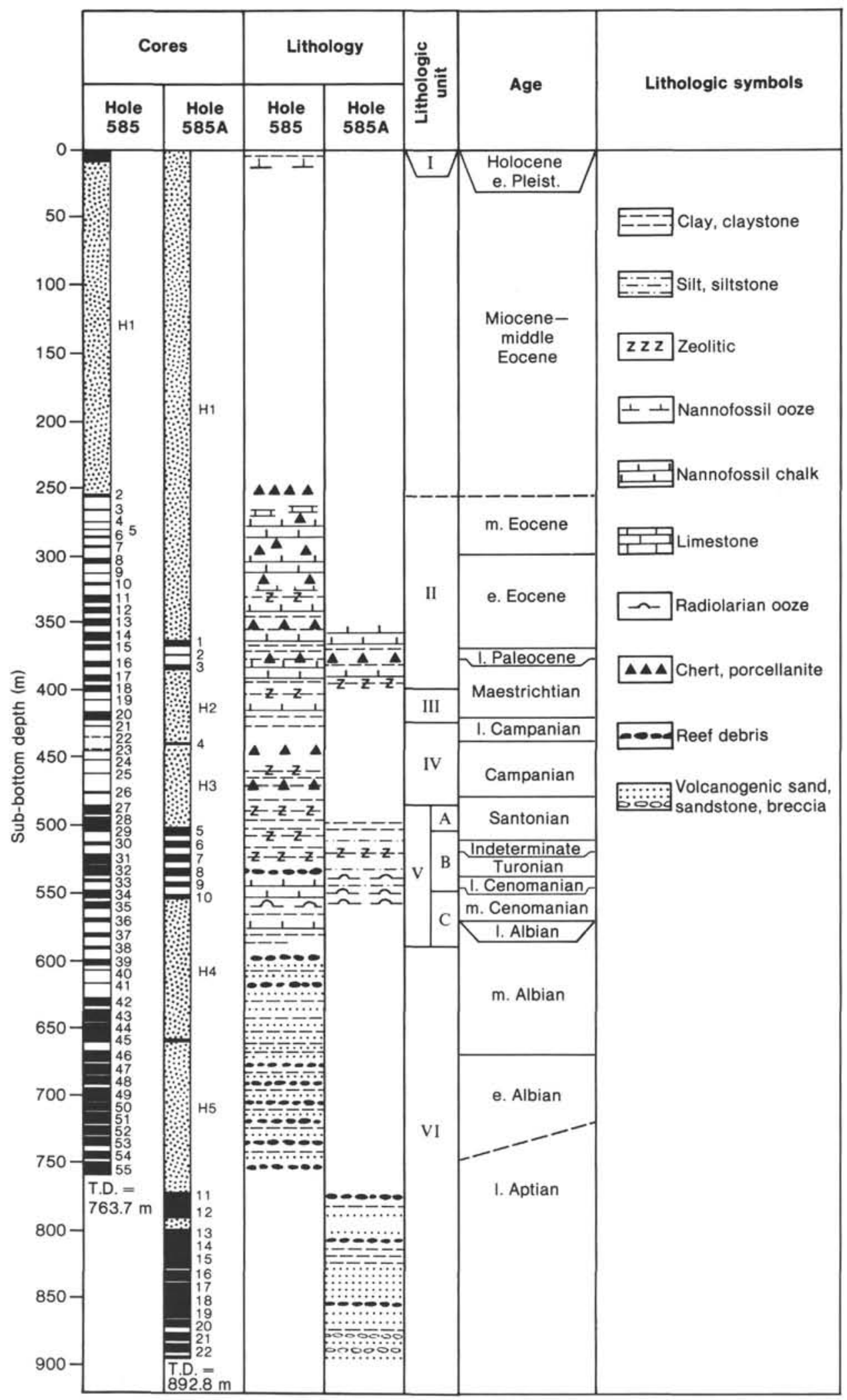

Figure 2. Columnar section showing core recovery, general lithology, and age for Holes 585 and 585A, DSDP Leg 89, Mariana Basin. (Core recovery is shown in black; stipled pattern = washed interval.) 
W. V. SLITER

Table 1. Distribution of Cretaceous redeposited benthic foraminifers at Hole 585 .

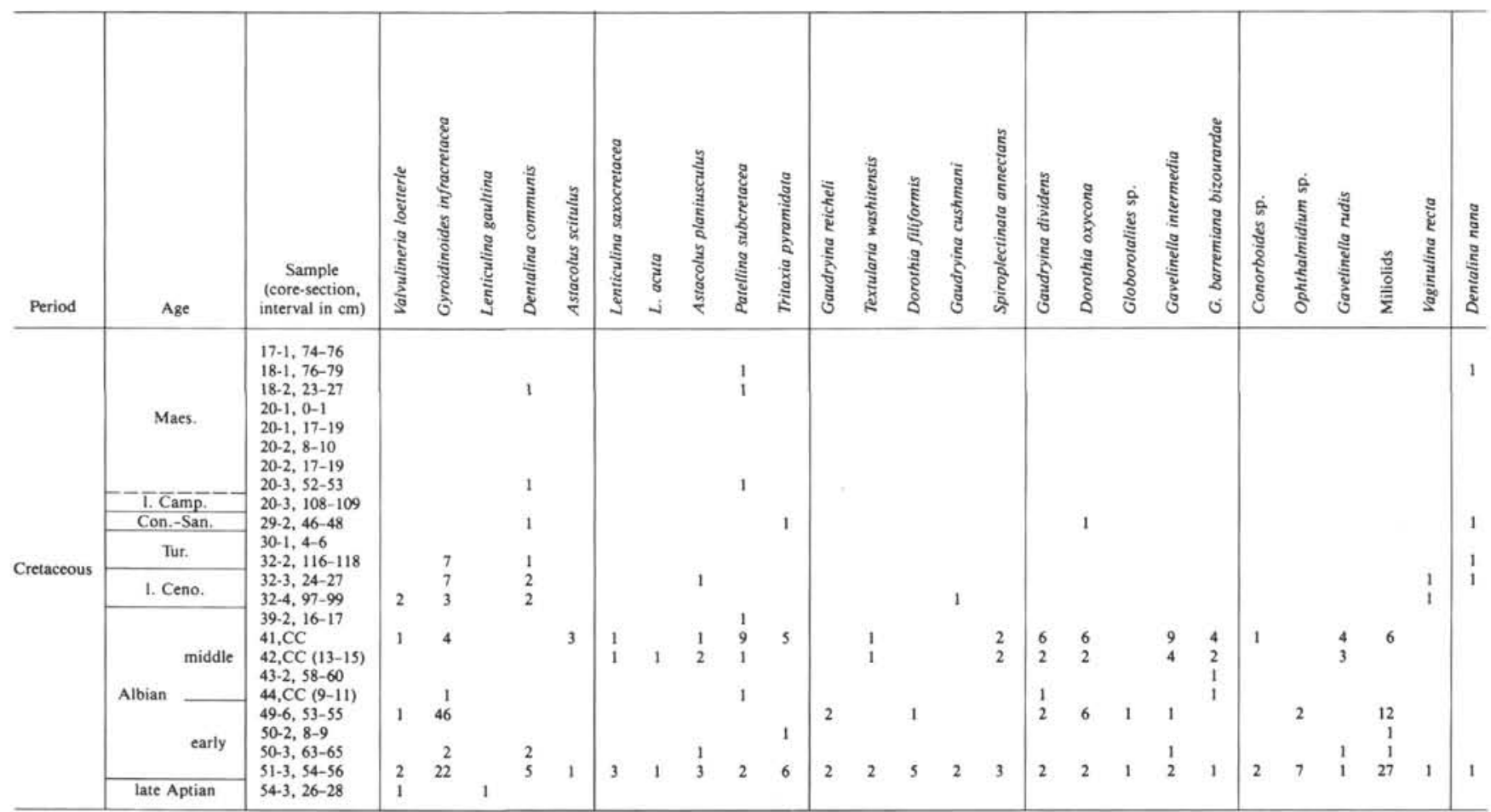

Note: Abundances are based on total fauna recovered from $20-\mathrm{cm}^{3}$ samples greater than $42 \mu \mathrm{m}$.

Table 1 (continued).

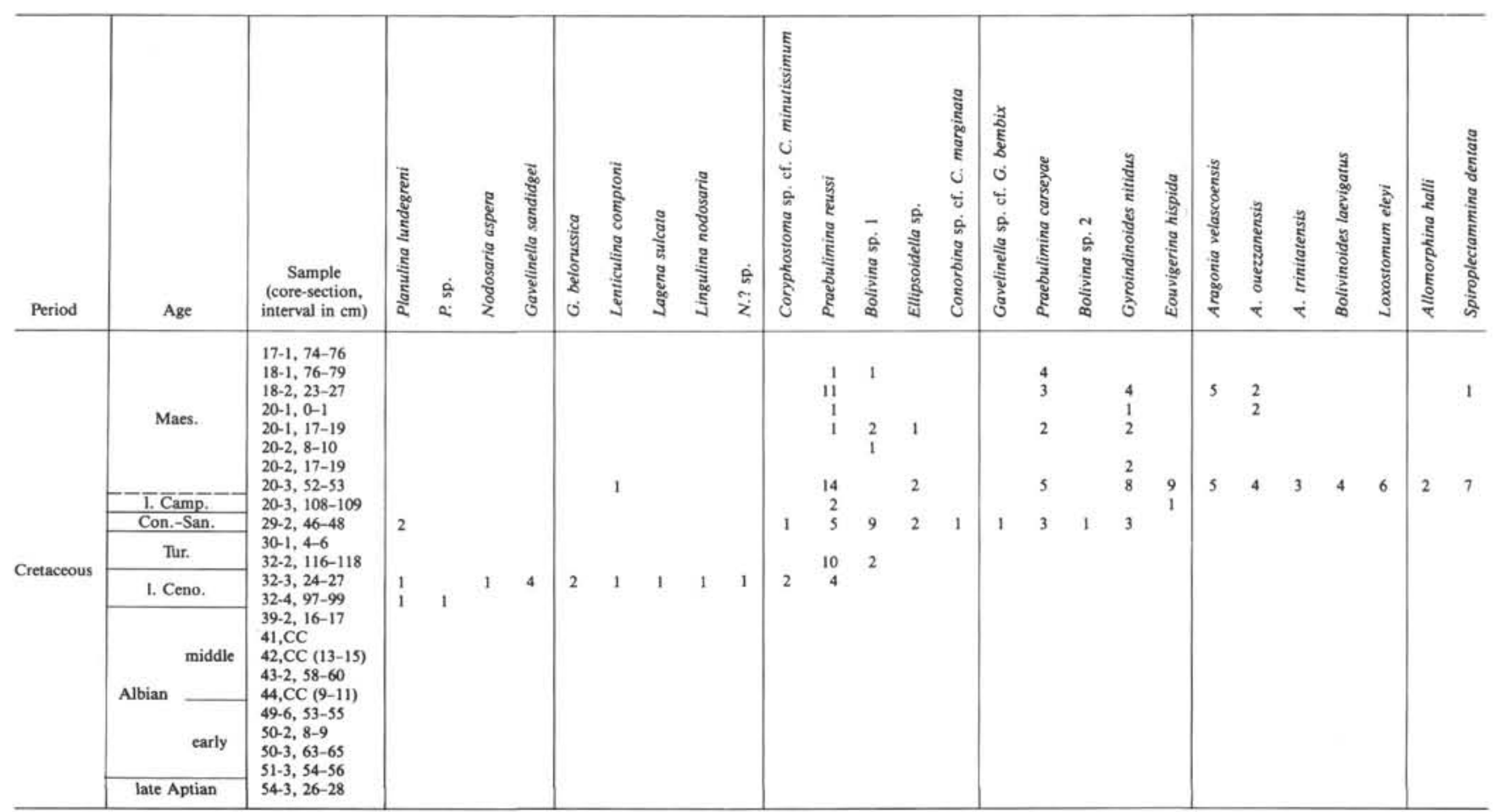


Table 1 (continued).

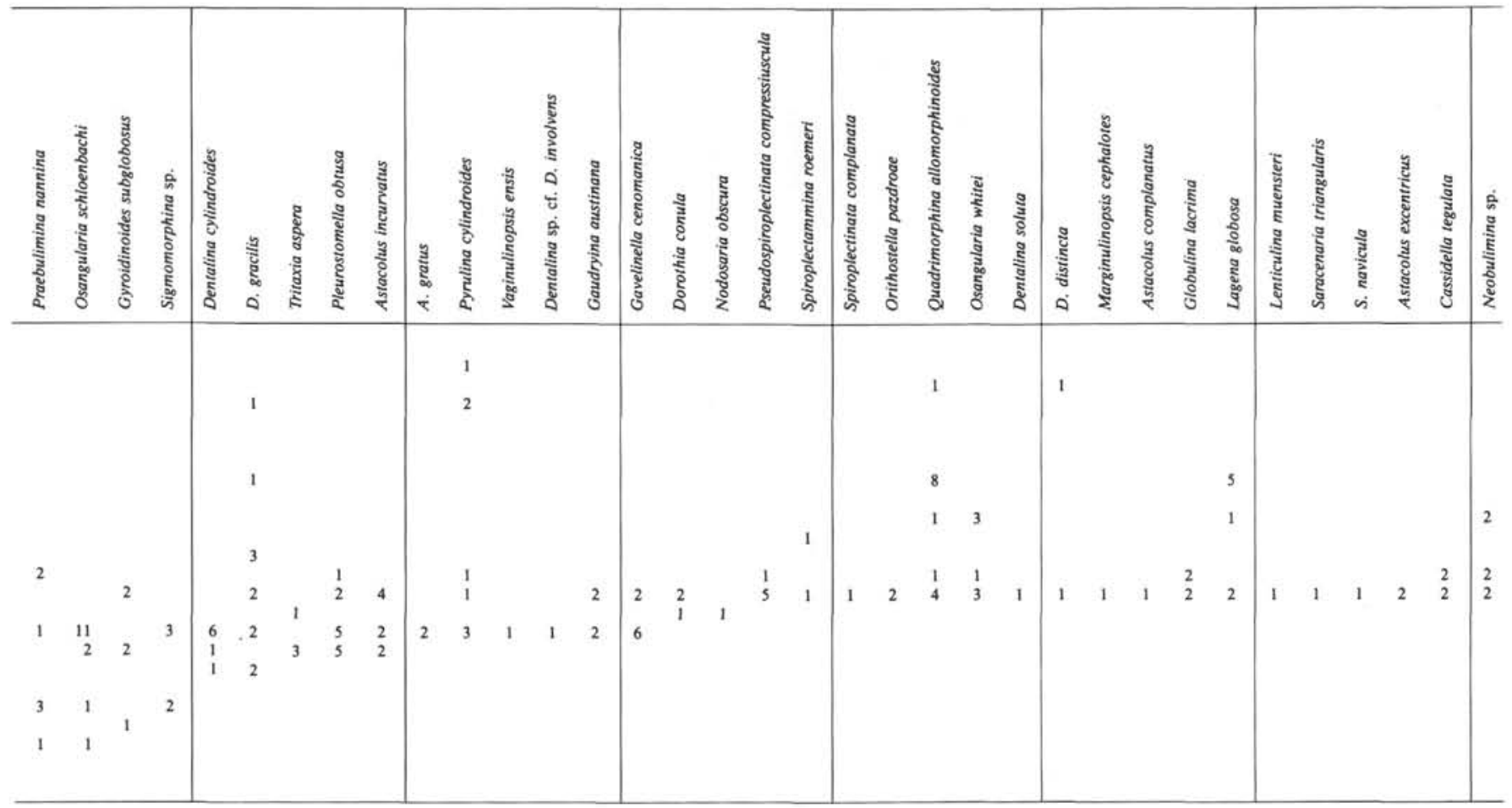

Table 1 (continued).

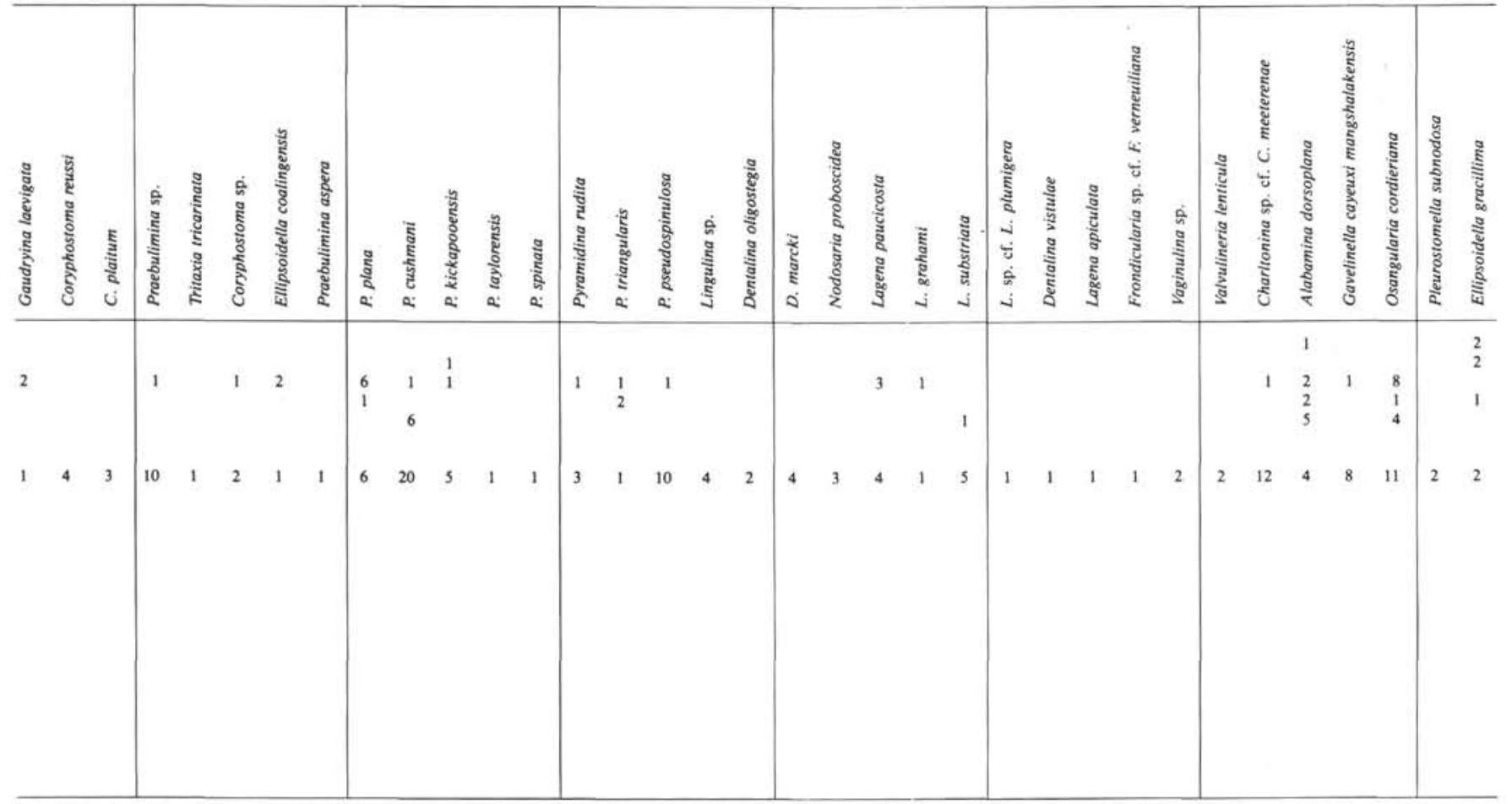


Table 1 (continued).

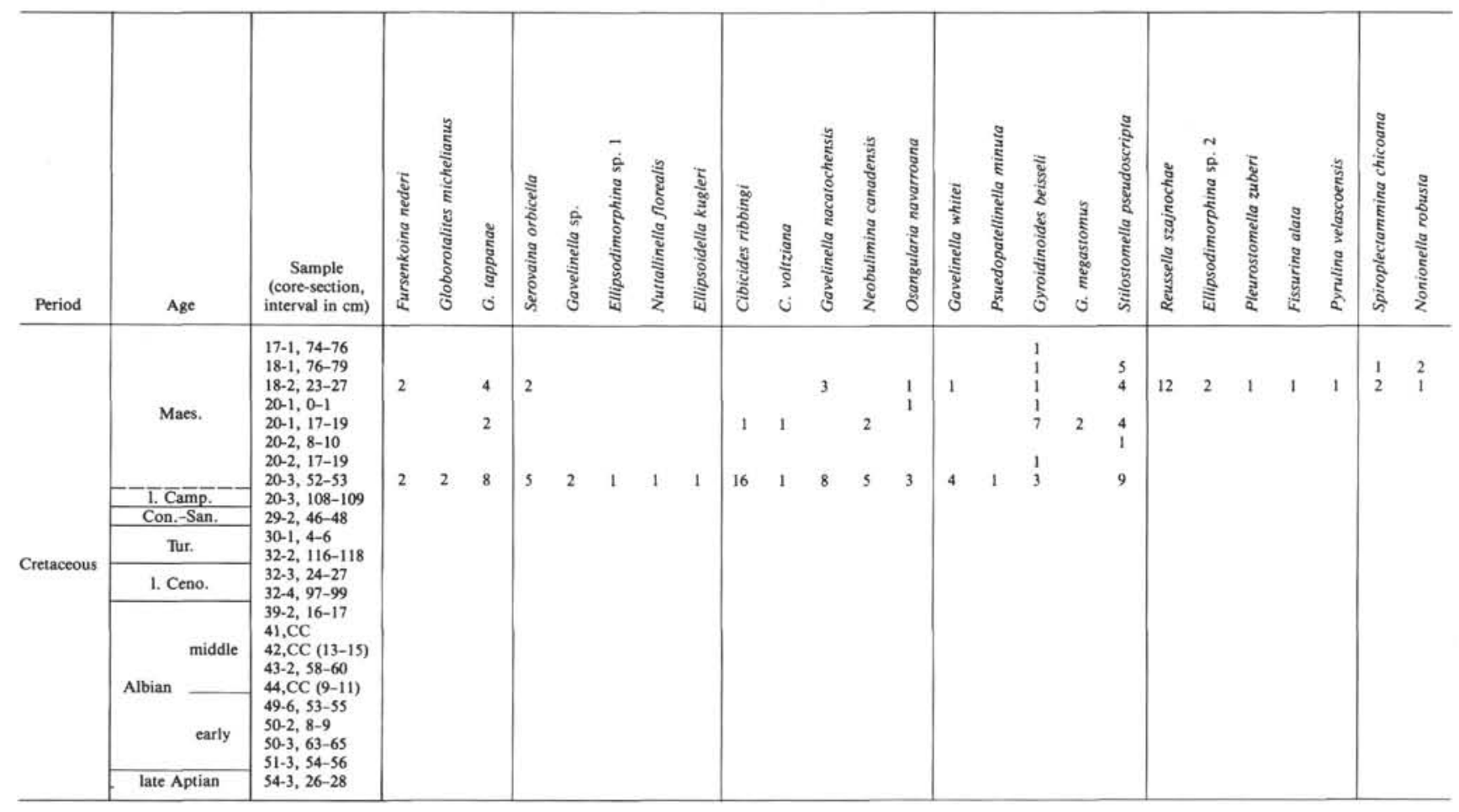

si, Gavelinella sandidgei, Planulina lundegreni, and Osangularia whitei.

In Hole 585A, Core 585A-9 contains the Cenomanian/Turonian boundary. The allochthonous benthic faunas from this core contain a mixed late CenomanianTuronian assemblage that includes Valvulineria loetterle, Praebulimina nannina, Pleurostomella obtusa, Planulina lundegreni, and Gavelinella sp. cf. G. ammonoides.

\section{Coniacian-Santonian}

Core 585-29 of Hole 585 is dated by radiolarians as Coniacian-Santonian (Schaaf, this volume). The allochthonous benthic assemblage from Sample 585-29-2, 46$48 \mathrm{~cm}$ contains the last occurrence of Planulina lundegreni, Osangularia whitei, and Gaudryina dividens and the first occurrence of Gyroidinoides nitidus, and Praebulimina carseyae. No allochthonous benthic faunas of this age were recovered from Hole 585A.

\section{Campanian-Maestrichtian}

In Hole 585, the Campanian/Maestrichtian boundary as recognized by calcareous nannofossils occurs between Sections 2 and 3 of Core 585-20 (Bergen, this volume). This placement may be too high, as shown by the distribution of displaced benthic foraminifers. Sample 585-20-3, 108-109 cm contains only very rare specimens of Praebulimina reussi and Eouvigerina hispida. These species do not differentiate the Campanian from the Maestrichtian. A much more abundant fauna is found in Sample 585-20-3, 52-53 cm. Species that appear in this sample include Aragonia ouezzanensis, A. trinitatensis, and Gavelinella cayeuxi mangshlakensis that together strongly suggest a Maestrichtian age. Elements of this assemblage continue to Core 585-18, in addition to species such as Reussella szajnochae, Spiroplectammina dentata, S. chicoana, Alabamina dorsoplana, Osangularia cordieriana, Gavelinella whitei, G. nacatochensis, and Pyrulina velascoensis. Sample 585-17-1, 74$76 \mathrm{~cm}$ contains a much reduced fauna consisting of very rare specimens of Alabamina dorsoplana, Ellipsoidella gracillima, and Gyroidinoides beisseli.

In Hole 585A, the Maestrichtian interval dated by radiolarians and nannofossils is represented by rare redeposited benthic species from Core 585A-3 that include Praebulimina carseyae, Gavelinella sandidgei, and Ellipsoidella gracillima.

\section{PALEOECOLOGY OF SOURCE ENVIRONMENTS}

Benthic foraminifer assemblages from redeposited sediments represent an important tool for interpreting the paleoecology of source environments. Information on the presence, stratigraphy, and depositional environment of the source area can often be determined by analyzing these assemblages. Although information from displaced and reworked contemporaneous deep-water sediments is often difficult to interpret due to similarity of the indigenous assemblages, transported assemblages from shallow-water environments displaced into abyssal environments are easily recognized. This is especially true at Site 585 where shallow- and deep-water carbonates were sporadically deposited well below the CCD since the Early Cretaceous.

Despite the obvious nature of the displaced material, it must be recognized that the resedimentation processes exert a strong influence on the transported assemblage. Selective winnowing of biogenic and lithologic components for size, shape, and weight, and the addition of material incorporated during sediment transport can al- 


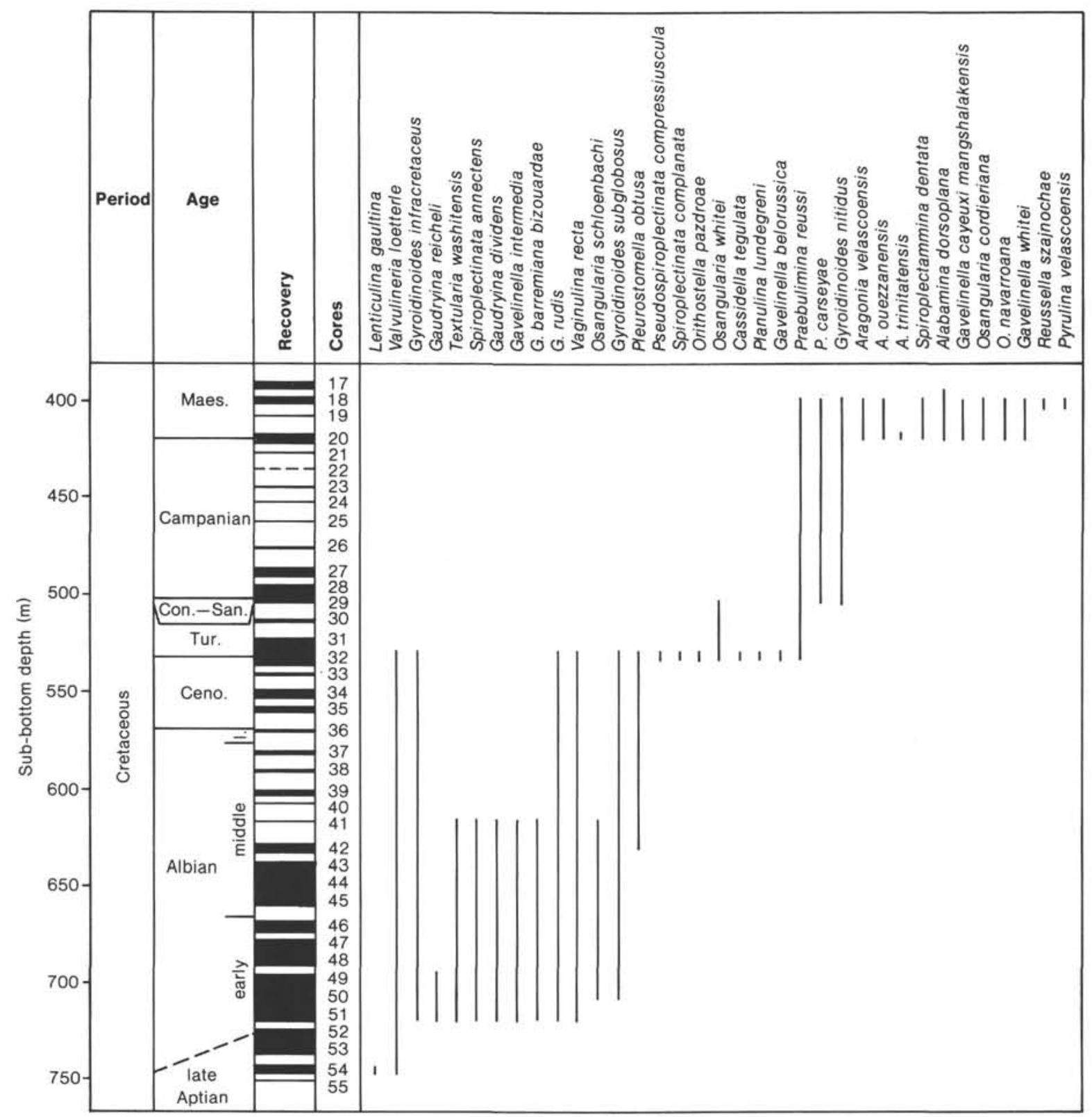

Figure 3. Stratigraphic distribution of selected benthic species at Hole 585. Biostratigraphic boundaries are based primarily on Bergen, Premoli Silva, and Schaaf (this volume).

ter the character of displaced assemblages. These effects are most pronounced in fine-grained deposits that result from gravity-flow transport over long distances. For example, in Mesozoic distal turbidites from the North Atlantic the effects of resedimentation and vertical sorting were observed both between the basal fine-grained sandstone and upper marlstone of a single turbidite, and between marlstone layers in a single turbidite (Sliter, 1980). Hence, less alteration of the source assemblage would be expected in a cohesive proximal gravity-flow deposit than in a distal turbidite of the same material.

Conversely, the mixed assemblages of distal deposits often can be used to interpret benthic environments traversed during sediment transport. The admixture of biogenic material incorporated during transit often contains species representative of specific upslope environ- ments. This of course assumes that adequate preservation, abundance, and diversity is represented in the assemblage, factors not always present in resedimented abyssal deposits.

In the following section, source environments are examined at Site 585 during four time intervals: AptianAlbian, Cenomanian-Turonian, Coniacian-Turonian, and Campanian-Maestrichtian (Figs. 4-5). Water depth ranges used in the bathymetric interpretations are:

inner neritic $(0-30 \mathrm{~m})$ middle neritic $(30-100 \mathrm{~m})$ outer neritic (100-200 m) upper bathyal $(200-500 \mathrm{~m})$ middle bathyal $(500-1500 \mathrm{~m})$ lower bathyal $(1500-3500 \mathrm{~m})$ abyssal $(>3500 \mathrm{~m})$ 
Table 2. Distribution of Cretaceous redeposited benthic foraminifers at Hole 585A.

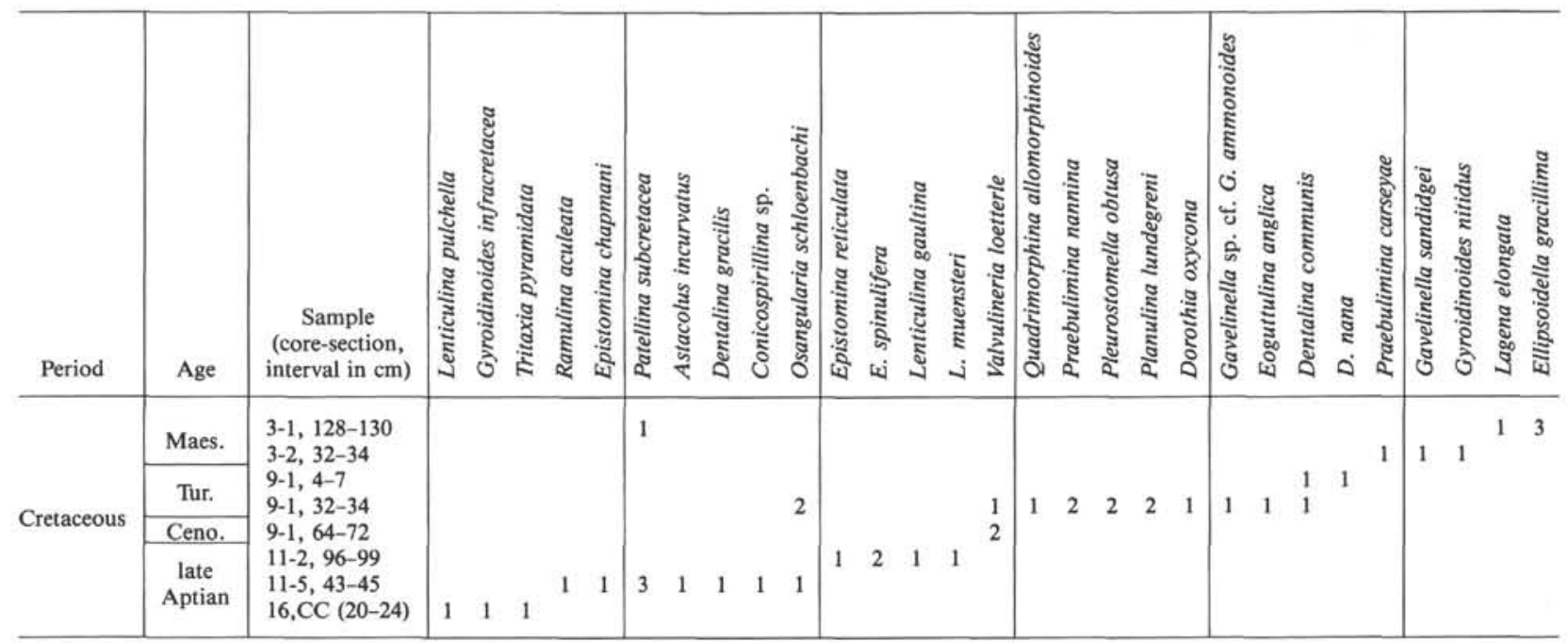

Note: Abundances based on total fauna recovered from $20-\mathrm{cm}^{3}$ samples greater than $42 \mu \mathrm{m}$.

\section{Aptian-Albian}

The oldest sequence recovered at Site 585 is represented by the late Aptian assemblage in Hole $585 \mathrm{~A}$, which is associated with graded sequences of volcaniclastic and coarse carbonate debris (Fig. 2). The fine-grained tops are laminated, massive, or bioturbated. Benthic assemblages are characterized by species of Epistomina, Patellina, Lenticulina, Astacolus, Tritaxia, Osangularia, and Dentalina. Other biogenic debris includes worn fragments of rudists and other bivalves, algae, echinoids, bryozoa, and crustaceans with orbitolinids and other large foraminifers in association with ooids and limestone fragments (Fig. 5). The Aptian assemblage contains the largest displaced benthic foraminifers recovered from Site 585 ; this assemblage is represented by specimens of Epistomina and Lenticulina. Shallow-water and innerneritic bank or reef environments above $30 \mathrm{~m}$ are interpreted for the dominant biogenic assemblage mixed with somewhat deeper, outer-neritic to upper-bathyal species of Osangularia and Gyroidinoides.

In Hole 585, the late Aptian to Albian sequence consists of graded sequences of volcaniclastics and coarse sandstone at the base that range upward into graded and fining-upward sequences of siltstone and claystone. Benthic assemblages are represented by species of Lenticulina, Astacolus, Gaudryina, Gyroidinoides, Dorothia, Tritaxia, Osangularia, and Gavelinella. Other biogenic material includes echinoid spines, ostracodes, bryozoa, algae, fragments of thin-shelled bivalves, and agglutinated foraminifers with complex wall structure together with ooids and glauconite (Fig. 4).

Several trends are noted in this sequence. There is an upward decrease in the size of individual specimens throughout the Albian interval. Nodosariids, represented by 18 species, decrease in diversity and abundance upward. Miliolids and ophthalmidiids decrease dramatically upward. A reversal in this trend is observed for species of Gyroidinoides, Gavelinella, and Osangularia, all of which increase in abundance upward.
These trends, combined with data from Hole 585A, represent a deepening of the source environment from shallow-water and inner-neritic late Aptian and early Albian environments associated with the coarse volcaniclastic debris flows at the base of the sequence, to predominantly outer-neritic to upper-bathyal, smaller-sized biogenic and lithologic material deposited by more distal turbidites at the top of the sequence. The appearance of the dominant outer-neritic to upper-bathyal assemblage in Cores 585-44 to -39 in the middle Albian of Hole 585 accompanies a change in lithology from the coarse volcaniclastics in the older section to more finegrained, presumed distal material (Fig. 4). Shallow-water biogenic and lithogenic components continue upward to Core 585-36 in the late Albian but are much reduced in abundance. The presence of rare volcanogenic debris in this interval suggests the continuation of intermittent volcanism and associated neritic environments, although the dominant redeposited material indicates that most of the source areas were subsiding. Members of the dominant bathyal assemblage include species of Osangularia, Gavelinella, Pleurostomella, as well as agglutinated genera.

\section{Cenomanian-Turonian}

Faunal components of the Cenomanian to Turonian sequence at Site 585 record a continued deepening of the dominant source areas. Sediments consist of interbedded calcareous claystone and radiolarian clay that grade upward into dark gray claystone with fine laminations and rare fining-upward graded sequences. Foraminifers present include species of Gavelinella, Gyroidinoides, Pseudospiroplectinata, Quadrimorphina, Osangularia, Praebulimina, Neobulimina, Pleurostomella, and Coryphostoma. Nodosariids are amply represented by 22 species of genera such as Dentalina, Astacolus, Lenticulina, and Nodosaria among others. Redeposited material from neritic-source areas is represented by rare species of Vaginulina, Pyrulina, Marginulinopsis, and fistulose polymorphinids together with rare carbona- 


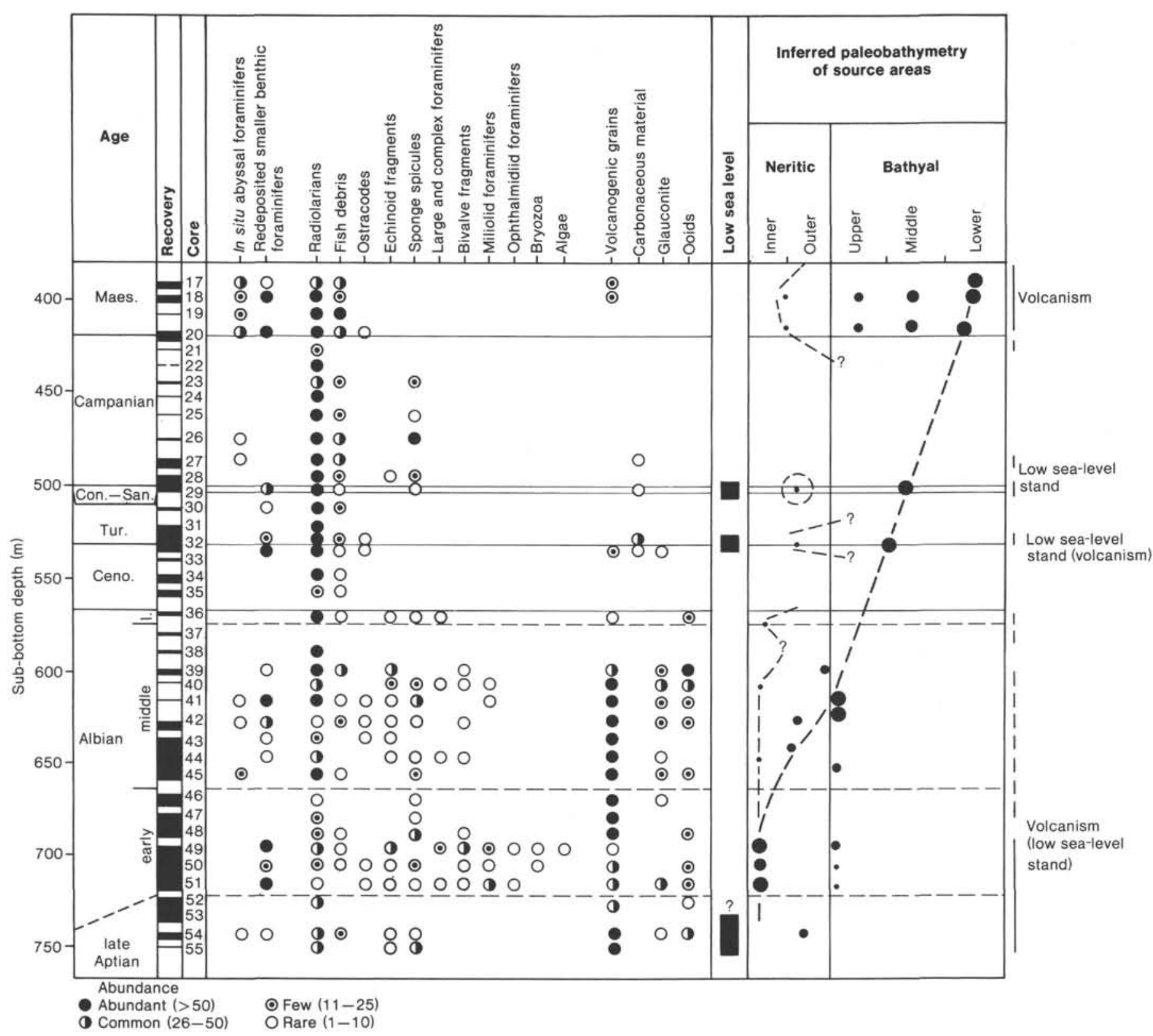

Figure 4. Distribution of selected biogenic and lithogenic components of Hole 585 and the inferred paleobathymetric interpretation. Abundance of biogenic and lithogenic components is based on total assemblage greater than $45 \mu \mathrm{m}$. Relative abundance of displaced benthic foraminifers (both larger and complex shallow-water species and smaller neritic, bathyal, and abyssal species) is shown by size of symbol. Heavy dashed line shows trend of dominant displaced benthic assemblage. Light dashed line shows trend of shallowest displaced benthic assemblage. Core recovery is shown in black. Low eustatic sea-level stands after Kauffman (1973), Hancock (1975), and Vail and others (1977).

ceous material, glauconite, and ooids (Figs. 4-5). With the exception of rare ornamented ostracodes, fish debris, sponge spicules, and abundant recrystallized radiolarians, no other biogenic material was recovered in this interval. The presence of sparse volcanogenic debris suggests either nearby volcanic activity with associated neritic environments or, alternatively, erosion of contemporaneous material due to a global low sea-level stand. Upper- to middle-bathyal (200-1500 m) environments are proposed for the dominant source areas during the Cenomanian to Turonian. In fact, the abundance of praebuliminids in the Turonian interval argues for middle-bathyal (500-1500 m) depths.

\section{Coniacian-Santonian}

The single sample from the Coniacian-Santonian interval in Hole 585 contains a dominant fauna indicative of middle-bathyal source areas. Species of Quadrimorphina, Gyroidinoides, Osangularia, Gavelinella, Praebulimina, Neobulimina, and Ellipsoidella occur with a less abundant group of small-sized nodosariids and agglutinated species. Rare specimens of Conorbina and Planulina together with rare carbonaceous material implies the presence of neritic-source areas or, alternatively, the erosion and redeposition of shoaler source material (Fig. 4). No volcanogenic grains were observed. The 


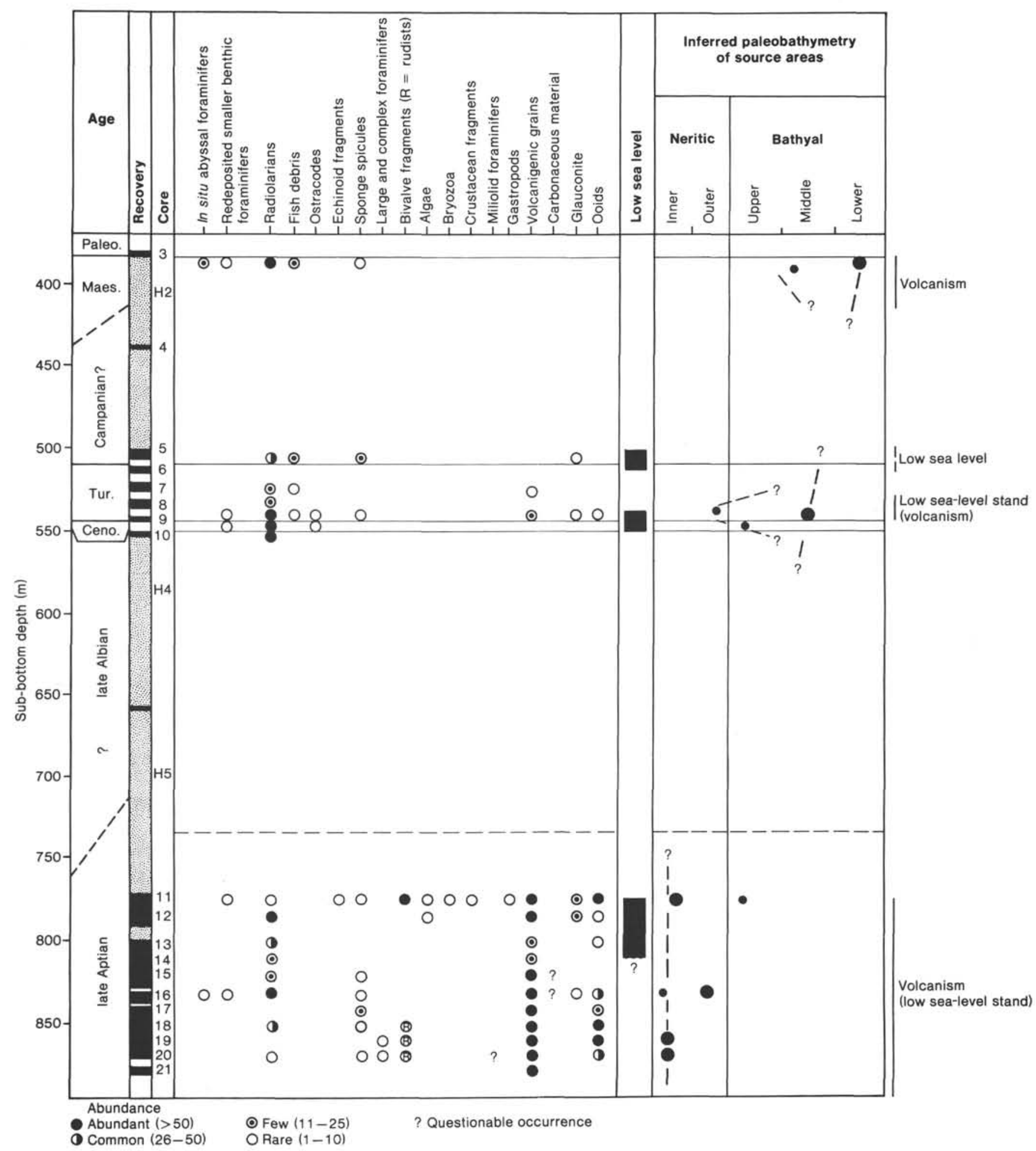

Figure 5. Distribution of selected biogenic and lithogenic components of Hole 585A and the inferred paleobathymetric interpretation. Abundance of biogenic and lithogenic components is based on total assemblage greater than $45 \mu \mathrm{m}$. Relative abundance of displaced benthic foraminifers (both larger and complex shallow-water species and smaller neritic, bathyal, and abyssal species) is shown by size of symbol. Heavy dashed line shows trend of dominant displaced benthic assemblage. Light dashed line shows trend of shallowest displaced benthic assemblage. Core recovery is shown in black; stipled pattern = washed interval. Low eustatic sea-level stands after Kauffman (1973), Hancock (1975), and Vail et al. (1977). 
dominant lithology is dark claystone with faint laminations and minor bioturbation. The remaining biogenic material consists solely of bathyal elements composed of recrystallized radiolarians, fish debris, and sponge spicules from the indigenous deep-abyssal assemblage.

\section{Campanian-Maestrichtian}

Displaced benthic faunas increase in abundance and diversity during the Maestrichtian interval. Recovery during the Campanian interval at Site 585 was severely limited because of increased silicification. Samples from the zeolitic claystone and silicified chalk from the Campanian interval showed only elements of the indigenous deepabyssal assemblage. In the Maestrichtian interval, redeposited assemblages were recovered from nannofossil claystone, calcareous claystone, and nannofossil chalk that showed occasional fine laminae and some subtle grading. The Maestrichtian assemblage is represented by species of Aragonia, Gavelinella, Gyroidinoides, Praebulimina, Osangularia, Coryphostoma, Ellipsoidella, Stilostomella, Nuttallinella, Charltonina, Pleurostomella, Fursenkoina, Reussella, and Ellipsodimorphina. Associated biogenic material consists of very rare ostracodes and members of the indigenous deep-abyssal assemblage. This dominant assemblage is indicative of lower bathyal environments ( 1500 to $3500 \mathrm{~m}$ ) above the CCD (Figs. 4-5). Mixing of benthic environments is indicated by species of Nonionella, Cibicides, Vaginulina, Bolivinoides, juvenile specimens of Frondicularia, and the abundance and diversity of praebuliminids. Middle-neritic to middle-bathyal paleodepths of from 30 to $1500 \mathrm{~m}$ are proposed for the less abundant mixed components. Juvenile specimens of large nodosariids and specimens of Nonionella and Cibicides identify neritic depths, whereas the abundance and diversity of the praebuliminids indicate middle-bathyal depths. Transported assemblages from this interval thus are strongly lower bathyal in character but include common middle-bathyal elements and rare members of the middle-neritic to upper-bathyal assemblages. The mixed assemblage suggests that the tops of surrounding seamounts were uplifted to within or close to middle-neritic depths. Presence of the neritic assemblage together with volcanogenic grains in Maestrichtian samples from Hole 585 evidences a further episode of shallow-water edifice-building volcanism within the region.

\section{GEOLOGIC HISTORY}

The transported material deposited in the Mariana Basin during the Cretaceous provides a record of the geologic history of the surrounding seamounts. The record identifies: early Albian and older edifice-building volcanism; subsequent subsidence with renewed volcanism and uplift during the Late Cretaceous; episodic pulses of sedimentation due to volcanism and to changes in sea level; accumulation of carbonate and chert during the Late Cretaceous as the site passed beneath the equatorial productive zone with northwestward plate motion; and periods of oceanic anoxia.

Redeposited lithogenic and biogenic material from the Albian to the Maestrichtian record the cessation of ma- jor volcanism and the gradual subsidence of nearby volcanic edifices to water depths of 500 to $1500 \mathrm{~m}$ in the Turonian to Santonian. Renewed volcanism and uplift of the seamounts in the Maestrichtian is reflected by a shoaling of source areas. Coarse volcanogenic turbidites and debris flows of hyaloclastite debris and shallow-water skeletal material from the base of Site 585 show that seamounts surrounding the East Mariana Basin had built to sea level by Aptian time. This early phase of edificebuilding volcanism began in Aptian or older time in the western Pacific, as evidenced from basalt sheet flows with minor pillowed units recovered from the bottom of Site 462 in the Nauru Basin of the western Marshall Islands (this volume). Shallow-water and inner-neritic foraminifers, other biogenic material, and ooids from Site 585 indicate the presence of bank or reef environments within the photic zone. This shallow-water material was transported and deposited on the floor of the Mariana Basin that was already at a depth of 5000 to $6000 \mathrm{~m}$, as evidenced from the indigenous deep abyssal assemblage of agglutinated benthic foraminifers, recrystallized radiolarians, fish debris, and sponge spicules. Characteristically, the abyssal assemblage is found in reddish brown claystone that represents pelagic sedimentation between turbiditic episodes. Benthic foraminifers in the indigenous abyssal assemblage include species of Glomospira, Glomospirella, Ammodiscus, Hyperammina, Bathysiphon, Paratrochamminoides, Saccammina, Haplophragmoides, Recurvoides, and Trochamminoides. Elements of this fauna are found in Cores 585-15 to 585-54 and Cores $585 \mathrm{~A}-3$ to $585 \mathrm{~A}-16$, which indicates that the entire sequence from late Aptian to Recent at Site 585 was deposited at abyssal depths (Figs. 4-5).

A progressive deepening of the source areas to outerneritic or upper-bathyal depths during the Albian accompanied the cessation of major volcanism. By middle Albian, the earlier coarse volcanogenic sediments graded into fine-grained sediments deposited by distal turbidites. Redeposited faunas indicating dominantly upperto middle-bathyal depths are found in the Cenomanian to Turonian interval and appear to continue to the Coniacian-Santonian.

A major change in sedimentation occurred in the Campanian and Maestrichtian, as evidenced by the presence of abundant chert, nannofossil chalk, and siliceous limestone above older zeolitic claystone. The change in sedimentation reflects passage of the site beneath the equatorial zone of high biologic productivity due to northwestward plate motion and the resultant increase in pelagic siliceous and carbonate sediments. Accompanying the change in sedimentation is an apparent change in water depth of the source environments. Rare benthic foraminifers from middle-neritic to upper-bathyal environments appear throughout the sequence, indicating an uplift of the source areas. Thin beds and laminae of redeposited hyaloclastic material during this interval in Hole 585 record minor pulses of volcanic activity that may have been associated with the Campanian to Maestrichtian volcanism observed in the Nauru Basin. Accordingly, seamounts surrounding the Mariana Basin apparently underwent thermally induced regional uplift 
associated with midplate volcanism as did those in areas to the south and east of Site 585 in the western North Pacific (Schlanger and Premoli Silva, 1981).

Deposition of Cretaceous displaced material at Site 585 was episodic with major pulses in the Aptian-Albian and Maestrichtian and minor pulses during the $\mathrm{Ce}$ nomanian-Turonian and possibly the Coniacian-Santonian (Figs. 4, 5). Resedimentation events on a regional scale within the western Pacific were noted by Thiede, Dean, et al. (1981) and correlated, in part, with times of low eustatic sea-level stands. Eustatic curves proposed by several authors show several low stands of sea level during the Late Cretaceous (Kauffman, 1973; Hancock, 1975; Vail et al., 1977). In general, low stands are recognized during the late Aptian, the Cenomanian, and possibly the Coniacian (Figs. 4,5 ). These time periods correspond with several pulses of resedimentation observed in the Mariana Basin. The late Aptian to Albian pulse at Site 585 appears directly related to edifice-building volcanism. The volume of material redeposited, however, may have been enhanced by the lowering of the sea level especially during the late Aptian. Major volcanism ceased by middle Albian, and the majority of source areas were subsiding. Recovery of rare shallow-water material and volcanogenic debris in the late Albian suggests a continuation of intermittent volcanism. The Cenomanian-Turonian pulse apparently is related directly to the lowering of sea level (Figs. 4-5). Redeposited neritic material and volcanogenic debris during this interval may have been remobilized by contemporaneous erosion. Alternatively, or perhaps concomitantly, sporadic volcanic activity may have been a contributing factor by providing shallow source areas. Likewise, the rare displaced material during the Coniacian-Santonian interval corresponds to a minor low sea-level stand (Figs. 4, 5). Maestrichtian resedimentation, however, does not correspond to major eustatic change and more likely is related to renewed midplate volcanism that uplifted the nearby seamounts.

Organic, carbon-rich layers are present in the Cenomanian-Turonian sequence at Site 585. In Hole 585, the dark layer lies within a turbidite sequence in Section 58532-3 just below the Cenomanian/Turonian boundary as determined by planktonic foraminifers. The layer is composed of diverse, recrystallized radiolarians of variable size, and the organic carbon is of marine algal origin (Site 585 report, this volume). Benthic foraminifers from above and below the layer in Sections 585-32-3 and 58532-2 consist of species most representative of upper- to middle-bathyal environments mixed with rare elements of the indigenous deep-abyssal assemblage. The Cenomanian assemblage from Sample 585-32-3, 24-27 cm is characterized by species of Gyroidinoides, Osangularia, Praebulimina, Coryphostoma, and nodosariids. The Turonian assemblage from a turbidite above the organic layer in Sample $585-32-2,116-118 \mathrm{~cm}$ is dominated by species of both Praebulimina and Gyroidinoides. Water depths that deepened from upper-bathyal to middlebathyal are interpreted for this sequence. In Hole $585 \mathrm{~A}$, a black layer was recovered from Sample 585A-8,CC again close to the Cenomanian/Turonian boundary but somewhat younger in age than the layer in Hole 585. As in Hole 585, the dominant displaced fauna from the Turonian sequence of Hole $585 \mathrm{~A}$ is indicative of middlebathyal water depths, based on the assemblage that includes species of Osangularia, Praebulimina, Pleurostomella, Gavelinella, and Quadrimorphina among others.

The pervasive redeposited fauna from the sedimentary interval containing the organic layers indicates that the oxygen-deficient depositional environment was situated at intermediate water depths. This material, originally deposited on the tops and flanks of the submerged seamounts, was remobilized and transported to the $\mathrm{Ba}-$ sin floor by turbidites. Bioturbation throughout the sedimentary interval indicates the contemporary existence of oxygenated deep water within the Mariana Basin lying beneath oxygen-depleted intermediate water. Similar carbon-rich sediments of Barremian to Turonian age have been recovered from the tops and flanks of oceanic topographic highs in the North Pacific drilled during the Deep Sea Drilling Project. These include Sites 305 and 306 from Shatsky Rise (Larson, Moberly, et al., 1975), Site 317 from Manihiki Plateau (Schlanger, Jackson, et al., 1976), Sites 310, 465, and 466 from Hess Rise (Larson, Moberly, et al., 1975; Thiede, Vallier, et al., 1981), and Sites 171 and 463 from the Mid-Pacific Mountains (Winterer, Ewing, et al., 1973; Thiede, Vallier, et al., 1981). Similar carbon-rich limestone of Albian or older age from the Franciscan Complex of California and southwestern Oregon document the existence of oxygendeficient water throughout a wide region of the Cretaceous Pacific Ocean. Presumably formed on the eastern flank of the Pacific-Farallon ridge or on other active spreading ridges in low-latitude environments (Sliter, 1984), the California and Oregon deposits indicate that the oxygen deficient conditions were not confined to a single basin or to western North Pacific areas.

\section{COMPARISON WITH OTHER PACIFIC DSDP SITES}

DSDP Site 199, located $70 \mathrm{~km}$ west of Site 585 at a water depth of $6090 \mathrm{~m}$, penetrated Late Cretaceous sediments consisting of nannofossil chalk, siliceous limestone, chert, and reddish brown zeolitic tuff. Late Maestrichtian planktonic foraminifers described by Krasheninnikov and Hoskins (1973) are rare, largely reworked, and show signs of dissolution, which led the authors to speculate that deposition of the largely nannofossil limestone took place at depths near the CCD. Nannofossils described by Hekel (1973) likewise were strongly reworked and were attributed to the late Campanian to earliest Maestrichtian. The sediments recovered in Cores 199-12 and 199-13 led the shipboard party to conclude in the Site 199 report that (1) the tuffs reflected nearby Late Cretaceous volcanism, and (2) the pelagic limestone was deposited at a much shallower depth than the present abyssal setting. Although evidence of Late Cretaceous volcanism agrees with data from Site 585, the present paleontologic evidence would indicate that the pelagic carbonate was redeposited at abyssal water depths well below the CCD.

DSDP Sites 200, 201, and 202, drilled on the summit of Ita Maitai Guyot, approximately $70 \mathrm{~km}$ south of Site 585, penetrated early Eocene to Quaternary winnowed 
foraminiferal ooze. This sequence is underlain by oolitic limestone of pre-Eocene age that caps the Guyot at a water depth of about $1500 \mathrm{~m}$ (Heezen, MacGregor, et al., 1973). Although no identified Cretaceous material was recovered during this drilling operation, subsequent dredge hauls by the Kana Keoki taken from the Guyot recovered Inoceramus-bearing limestone (S. Schlanger, personal communication, 1983). This material indicates that shallow-water limestone was being deposited on the more elevated summit of the Guyot presumably during the Late Cretaceous.

At Site 462 , drilled in the Nauru Basin west of the Ralik Chain of the Marshal islands at a water depth of $5189 \mathrm{~m}$ and reoccupied during Leg 89 , basalt sills and flows overlain by Cretaceous sediments were recovered. The oldest fossiliferous sediments consist of a fragment of volcaniclastic, silty sandstone interlayered in the igneous sequence from Core 462A-99 with radiolarians of Late Jurassic to earliest Aptian age. An interlayered hyaloclastite with faint horizontal and cross-laminations recovered from Section 462A-80-1 during Leg 61 contains size-sorted radiolarians that were thought to be of Barremian age (de Wever, 1981) but are now placed in the early Aptian (Schaaf, this volume). Associated biogenic material includes abyssal foraminifers and fish debris. A late Aptian nannofossil assemblage from laminated claystone in Core 462A-40 within the igneous sequence also contains abyssal agglutinated foraminifers, radiolarians, fish debris, sponge spicules, and plant debris. Overlying the volcanogenic complex is a sequence of late Albian to early Campanian zeolitic claystones with interbeds of laminated volcaniclastics and zeolitic marlstone to claystone cycles near the top. Microfossils commonly are size sorted and reworked. The upper unit consists of upper Campanian to lower Maestrichtian volcaniclastic sediments with limestone, nannofossil marl, and calcareous claystone. Especially noteworthy is the redeposited shallow-water material that includes larger foraminifers, rudists, red algae, bryozoans, and echinoid debris.

The following summary of the geologic history of the Nauru Basin and the surrounding seamounts shows correlation to the area of the Mariana Basin:

1. late Aptian or older edifice-building volcanism with plant material derived from nearby volcanic islands

2. deposition at abyssal depths in the Nauru Basin from at least the late Aptian to the present

3. cessation of major volcanism from the late Albian through the Santonian with redeposition of fine-grained volcanic material (this sequence includes the first influx of redeposited bathyal benthic foraminifers in Core 46257 of Coniacian to early Santonian age)

4. renewed volcanism in the late Campanian to early Maestrichtian with elevation of the seamounts to within the photic zone and redeposition of shallow-neritic material derived from shallow bank or reef environments

5. subsidence of the seamounts from middle Maestrichtian to the present.

Schlanger and Premoli Silva (1981) synthesized data from previous DSDP sites and concluded that a large area of the central Pacific from the Nauru Basin-Marshall Islands on the west, to the Line Islands on the east, to the Mid-Pacific Mountains on the north underwent thermally induced uplift during the Late Cretaceous. These sites, drilled on topographic highs, record the buildup of volcanic edifices and the development of reef faunas from about 115 to 110 and $70 \mathrm{Ma}$. Most noteworthy were the buildup of Aptian to Cenomanian rudistid-coral reefs and the later Campanian to Maestrichtian reefs. The synthesis included Sites 165, 315, and 316 along the Line Islands (Winterer, Ewing et al., 1973; Schlanger, Jackson, et al., 1976); Sites 171, 313, and 463 from the Mid-Pacific Mountains (Winterer, Ewing, et al., 1973; Larson, Moberly, et al., 1975; Thiede, Vallier, et al., 1981); Sites 166, 169, and 170 from the central Pacific (Winterer, Ewing, et al., 1973); and Site 167 from Magellan Rise (Winterer, Ewing, et al., 1973). To these, Site 585 from the Mariana Basin can now be added, as well as Sites 464,465 , and 466 from Hess Rise (Thiede, Vallier, et al., 1981), and possibly Site 305 from Shatsky Rise (Larson, Moberly, et al., 1975). As a result, the area of midplate volcanism in the central Pacific is extended to the Caroline Islands in the west and possibly to Shatsky Rise or certainly to Hess Rise in the north. The thermally induced uplift of this region during at least two major periods in the Late Cretaceous contributed to the remobilization of the shallow-water material and to the subsequent deposition in the surrounding abyssal basins such as the Mariana and Nauru basins. The data show that the mechanisms driving the pulses of resedimentation recognized in the Mariana Basin are not derived locally but are of regional extent.

\section{CONCLUSIONS}

Summarizing the data derived largely from Cretaceous benthic foraminifers from Site 585 , the following sequence of events is proposed for the Mariana Basin and the surrounding Mesozoic seamounts: (1) early Albian and older volcanism resulted in edifice building that reached the photic zone with associated shallow-water bank or reef environments. Displaced material derived from the seamounts was deposited on the Basin floor at depths of 5000 to $6000 \mathrm{~m}$ that have existed since at least the late Aptian. (2) Subsidence of the seamounts began in the middle Albian with the cessation of major volcanic activity and proceeded to upper- to middle-bathyal depths by the Cenomanian-Turonian. Organic carbon-rich layers from sediment with an age near the Cenomanian/ Turonian boundary identify oxygen-deficient intermediate waters. (3) Coniacian-Santonian environmental conditions appear similar to those in the Cenomanian-Turonian and represent a continuation of middle-bathyal source areas. (4) Deposition of Campanian-Maestrichtian chert and nannofossil chalk with rare middle-neritic to upper-bathyal foraminifers and traces of volcanic material suggests remobilization and downslope transport of pelagic material due to thermally induced uplift. The increase in pelagic sedimentation resulted from the migration of the region beneath the equatorial productive zone as part of northwestward plate motion. (5) Episodic deposition of displaced material during the late Aptian to Albian was due to edifice-building volcanism perhaps augmented by a lowering of sea level. The Cenomanian-Turonian pulse of resedimentation appears 
related directly to a lowering of sea level as does the minor pulse during the Coniacian-Santonian. The Maestrichtian pulse is not related to sea-level fluctuation but to regional uplift that accompanied midplate volcanism.

\section{TAXONOMIC NOTES}

Alabamina dorsoplana (Brotzen)

(Plate 10, Figs. 4-5, 9)

The lenticular test, subangular periphery, strongly curved sutures on the spiral side, and interiomarginal aperture with sulcus identify this species, which is found persistently throughout the late Campanian to Maestrichtian interval of Hole 585 .

\section{Allomorphina halli Jennings}

(Plate 9, Fig. 9)

Small, subtriangular specimens have inflated chambers and a small aperture. These specimens differ from the larger Allomorphina cretacea Reuss with its subtriangular, involute test and wide aperture.

\section{Aragonia ouezzanensis (Rey)}

(Plate 9, Figs. 21-22)

This species is recognized by the widely flaring, thick test with a rhomboidal apertural outline, angular lateral margins, and narrow, arcuate chambers. It is a rare but persistent species throughout the late Campanian to Maestrichtian interval of Hole 585.

\section{Aragonia trinitatensis (Cushman and Jarvis)}

(Plate 9, Figs. 19-20)

Although considered a junior synonym of Aragonia velascoensis (Cushman) by Hillebrandt (1962) and Medizza (1969), the species is retained here for specimens with a widely flaring test, strongly raised sutures, and weakly developed surface ornamentation. These specimens occur together with specimens of $A$. velascoensis in a single sample from the late Campanian interval in Hole 585 and show no apparent intergradation. They differ from specimens assigned to $A$. velascoensis in the thicker, more flaring test, more prominent sutures, and more subdued surface ornamentation.

\section{Aragonia velascoensis (Cushman)}

(Plate 9, Figs. 16-18, 23)

Specimens with an ovate, compressed test, raised sutures, and reticulate surface ornamentation are assigned to this species.

\section{Astacolus excentricus (Cornuel) \\ (Plate 2, Figs. 11-12, 17-18)}

Specimens with a compressed test that tends to uncoil and narrow, arcuate chambers are assigned to this species. Similar forms are reported from Trinidad by Bartenstein, Bettenstaedt, and Bolli (1966), and Bartenstein and Bolli (1973).

\section{Astacolus gratus (Reuss) \\ (Plate 2, Figs. 13-14)}

Test is flattened, initial portion planispiral, later becoming arcuate with depressed sutures. Similar specimens were reported from Trinidad by Bartenstein, Bettenstaedt and Bolli (1966), and Bartenstein and Bolli (1973) and from off Morocco (Sliter, 1980).

Bolivina sp. 1

(Plate 6, Figs. 1-3)

Small, compressed specimens with 9 to 10 chambers and an irregular surface ornamentation are assigned to this species. The axial periphery is lobate in the later portion of the test and the chambers increase gradually in size. The aperture is a narrow, elongate loop up the chamber face with an internal tooth plate. Specimens range from 180 to $240 \mu \mathrm{m}$ in length and from 100 to $120 \mu \mathrm{m}$ in width. The species is most common in the Coniacian to Santonian interval of Hole 585 and ranges from the Turonian to the Maestrichtian. The morphology is very similar throughout the stratigraphic range, as shown by the figured specimens. The present specimens resemble those referred to Bo- livina sp. by Hemleben and Troester (1984) from the CampanianMaestrichtian of Site 543 (Hole 543A) in the North Atlantic Ocean.

Bolivina sp. 2

(Plate 6, Figs. 4-5)

A single specimen from the Coniacian-Santonian interval of Hole 585 has a flaring, compressed test, with a sharply rounded axial periphery and curved and slightly depressed sutures.

\section{Charltonina sp. cf. C. meeterenae (Visser)}

(Plate 11, Figs. 4-5, 9)

Specimens assigned to this species are trochospiral, biconvex, with a carinate periphery, and six chambers in the final whorl. The umbilicus is indented but closed. All chambers are visible on the spiral side and the sutures are strongly oblique; only the chambers of the last whorl are visible on the umbilical side and the sutures are radial to gently curved. The aperture is an elongate slit that extends from the umbilicus to the periphery and turns slightly into the apertural face. The morphologic features closely resemble the original illustration of this species, but the description fails to document the apertural characteristics. For this reason, a tentative assignment is made. The lack of a flangelike keel and the apertural characteristics distinguish this species from Epistominella alata (Marsson). The species was found in the late Campanian to Maestrichtian interval of Hole 585.

\section{Cibicides ribbingi Brotzen}

(Plate 8, Figs. 1-5)

Specimens from the late Campanian of Hole 585 show a wide variation in test shape. Small specimens are plano-convex, with a flattened spiral side, angular periphery, and gently convex umbilical side. The peripheral outline is lobulate and there are 7 to 8 chambers in the final whorl. The wall is coarsely perforate. Larger specimens become irregular in outline and tend to uncoil.

\section{Conicospirillina sp.}

(Plate 7, Figs. 4-5, 9)

A single specimen from the late Aptian interval of Hole 585A shows the convex, evolute spiral side and concave, nearly involute umbilical side characteristic of this genus.

\section{Conorbina sp. cf. C. marginata Brotzen}

(Plate 6, Figs. 14-16)

A small specimen from the Coniacian to Santonian interval of Hole 585 may represent a juvenile of this species. It differs in having a more rounded periphery and fewer chambers per whorl.

Conorboides sp.

(Plate 14, Figs. 14-16)

Several specimens recovered from the Albian interval of Hole 585 have a low trochospiral test with rounded periphery, open umbilicus, and four chambers in the final whorl. They are similar to specimens assigned to Conorbina brotzeni Gandolfi by Gawor-Biedowa (1972) but differ from the original description in being less high-spired and in having a rounded periphery, and an open umbilicus.

\section{Coryphostoma sp. ef. C. minutissimum (Cushman) \\ (Plate 9, Figs. 3-4)}

Specimens included here are small, elongate, and compressed with a rounded periphery. The chambers are initially subrectangular and biserial and become cuneiform, uniserial, and slightly inflated. The sutures are initially oblique, and become curved and slightly depressed. The aperture is terminal and oval. These features are similar to the original description, however, the present specimens differ in having less elongate chambers and a less lobate axial periphery. Furthermore, the Turonian to Santonian occurrence of the present forms is older than the stratigraphic level of the original description.

\section{Coryphostoma plaitum (Carsey) (Plate 9, Fig. 15)}

Very small specimens from Hole 585 show the general morphology of the species; elongate, narrow test with rounded periphery, subrec- 
tangular to cuneiform chambers, oblique sutures, as well as terminal aperture.

\section{Coryphostoma reussi (Geinitz)}

(Plate 9, Figs. 5-8)

Specimens assigned to this species are small, elongate, gently tapering, and compressed with a rounded periphery. The chambers are biserial in the initial portion of the test and later become cuneiform with a tendency toward becoming uniserial. Sutures are oblique and slightly depressed. The aperture is subterminal.

\section{Coryphostoma sp. \\ (Plate 9, Figs. 13-14)}

Several rare specimens from the late Campanian to Maestrichtian interval of Hole 585 show a similar morphology. The test is elongate, palmate, and compressed with a rounded periphery. Biserial chambers tend to become uniserial. Sutures are oblique and slightly depressed, and the aperture is subterminal. The specimens are somewhat similar to Bolivina sp. of Brotzen (1936) but differ in being smaller, more compressed, and having a subterminal aperture.

\section{Dentalina marcki Reuss}

(Plate 3, Fig. 1)

Elongate, gently arcuate specimens with an apical spine, longitudinal costae on all but the final chamber, and an excentric, radiate aperture are assigned to this species.

\section{Dorothia oxycona (Reuss) \\ (Plate 2, Figs. 4-6)}

Rare specimens assigned to this species range through the Albian to Coniacian-Santonian interval of Hole 585. The specimens are mostly small, poorly preserved, and distorted, making specific identifications difficult. Thus no attempt was made to subdivide the genus into more than the present species.

\section{Ellipsoidella coalingensis (Cushman and Church)}

(Plate 8, Figs. 18-20)

Small specimens from Hole 585 are elongate, tapering, with cuneiform, inflated chambers that become uniserial. The aperture is terminal and somewhat drawn out.

\section{Ellipsoidella gracillima (Cushman)}

(Plate 8, Fig. 22)

Specimens are elongate, slightly curved, initially biserial and later uniserial with distinct, slightly depressed sutures and a subterminal, arched aperture. The species is rare but persistent through the Campanian and Maestrichtian interval of Hole 585 and the Maestrichtian of Hole $585 \mathrm{~A}$.

\section{Ellipsoidella kugleri (Cushman and Renz)}

(Plate 8, Fig. 21)

A single specimen from the Campanian of Hole 585 shows the characteristics of this species. The test is elongate and circular in crosssection. Chambers are few, inflated, initially biserial and later uniserial. The aperture is terminal and elongate with a raised lip.

\section{Ellipsoidella sp.}

(Plate 8, Figs. 23-24)

Several small specimens from the Coniacian-Santonian to Maestrichtian interval of Hole 585 have an elongate, slightly curved test with a circular cross-section. Chambers increase gradually in size and appear to be initially biserial. Sutures are nearly horizontal and become slightly depressed. The aperture is terminal and slitlike. The species is a rare but persistent component of the fine size fraction.

\section{Ellipsodimorphina sp. 1}

(Plate 8, Figs. 12-13)

A single, robust specimen from the late Campanian of Hole 585 has an elongate test with an early biserial stage followed by a uniserial stage. The biserial stage is flattened with a distinctive carinate axial periphery. The ultimate chamber is inflated, rounded in section, and tends to become uniserial. The aperture is a terminal, elongate slit. The species differs from Ellipsodimorphina subtuberosa Liebus in the greater compression of the biserial stage and in the more angular, carinate periphery.

\section{Ellipsodimorphina sp. 2}

(Plate 8, Fig. 14)

Two, small, delicate specimens from the Maestrichtian of Hole 585 have an elongate test and a distinct early biserial stage with a rounded axial periphery followed by two cuneate, subglobular chambers. Sutures in the biserial portion are straight and flush and later become clearly depressed. The aperture is a terminal elongate slit.

\section{Epistomina chapmani ten Dam}

(Plate 15, Figs. 1-3)

A single, poorly preserved specimen from the late Aptian of Hole $585 \mathrm{~A}$ shows the arcuate spiral chambers, radial sutures on the umbilical side, as well as smooth surface ornamentation characteristic of this species.

\section{Epistomina reticulata (Reuss)}

(Plate 15, Figs. 4-5, 9)

A single, small, abraded specimen from the late Aptian of Hole $585 \mathrm{~A}$ is assigned to this species on the basis of the arcuate spiral chambers, gently curved umbilical sutures, and reticulate surface ornamentation over the closed umbilicus.

\section{Epistomina spinulifera (Reuss)}

(Plate 15, Figs. 6-8)

The curved spiral and umbilical sutures, and spinose, carinate margin identify the single specimen from the late Aptian of Hole 585A.

\section{Frondicularia sp. ef. $F$. verneuiliana d'Orbigny}

(Plate 3, Fig. 6)

A single, juvenile specimen recovered from the late Campanian of Hole 585 is tentatively assigned to this species.

\section{Gaudryina cushmani Tappan \\ (Plate 1, Figs. 9-10)}

Rare specimens in the late Albian to late Cenomanian interval of Hole 585 have an early, small, triserial portion of the test followed by a larger, conical, biserial portion. Chambers are broad and low and the sutures are distant and slightly depressed. The species differs from the younger Gaudryina frankei Brotzen in the more flaring, thicker test and the broader and lower chambers.

\section{Gavelinella barremiana bizouardae Maync}

(Plate 12, Figs. 14-16)

A few, poorly preserved specimens from the Albian interval of Hole 585 have the compressed test, subacute periphery, and oblique, curved sutures characteristic of early representatives of Gavelinella. The morphologic characteristics distinguish these specimens from those assigned to $G$. baltica, $G$. cenomanica, $G$. rudis, and $G$. intermedia.

\section{Gavelinella belorussica (Akimez)}

(Plate 12, Figs. 13, 17-18)

Two specimens from the Cenomanian of Hole 585 show the planoconvex test with an acute periphery, a prominent boss on the dorsal side, and the gently curved sutures characteristic of this species. Price (1977) placed the species in synonymy with Gavelinella intermedia var. A. (Berthelin) and notes, as did Malapris (1965), that the form is gradational with $G$. intermedia. The species is retained here, based on the distinctive morphology and stratigraphic occurrence, both of which differentiate these specimens from specimens that are attributed to $G$. intermedia.

\section{Gavelinella cenomanica (Brotzen)}

(Plate 13, Figs. 7-8)

Rare, poorly preserved specimens in Sample 585-41,CC from the late Albian interval of Hole 585 are assigned to this species on the basis of their compressed test with sharply rounded periphery, and their 
raised, curved sutures. The species was found together with Gavelinella intermedia and $G$. rudis.

\section{Gavelinella intermedia (Berthelin)}

(Plate 13, Figs. 6, 10)

This species is characterized by a sharply rounded periphery, small dorsal boss, small umbilicus on the flattened ventral side, and gently curved and depressed sutures. The species was recovered from the Albian interval of Hole 585 .

\section{Gavelinella rudis (Reuss) \\ (Plate 13, Figs. 14-19)}

Rare, but persistent specimens from the Albian to Cenomanian interval of Hole 585 are plano-convex with a convex spiral side and subangular periphery. The species differs from Gavelinella intermedia (Berthelin) in the greater convexity of the spiral side and more compact test, and from the younger $G$. sandidgei (Brotzen) in the greater test convexity and less acute periphery.

\section{Gavelinella sandidgei (Brotzen)}

(Plate 14, Figs. 1-5)

Rare specimens from the late Cenomanian to Coniacian-Santonian interval of Hole 585 and the Maestrichtian of Hole 585A are assigned to this species. The test is plano-convex; the spiral side is convex, partially evolute, and gently concave over the spiral area, and the axial periphery is subacute. Some specimens show a tendency to become elongate as did specimens from southern California (Sliter, 1968).

Gavelinella sp.

(Plate 14, Figs. 6-8)

Two specimens from the Maestrichtian of Hole 585 have a distinctive morphology that consists of a compressed, nearly biconvex test with a subacute periphery, 9 to 10 chambers in the final whorl that tend to become elongate, straight sutures that are initially flush and become slightly depressed, and an interiomarginal aperture.

Globorotalites sp.

(Plate 11, Figs. 14-16)

Two specimens from the Albian interval of Hole 585 are small with a plano-convex test, rounded periphery, oblique, flush sutures, and 7 to 8 chambers in the final whorl. They somewhat resemble Globorotalites alaskensis Tappan but are more strongly convex on the umbilical side and lack the lobate equatorial periphery. They differ from $G$. multisepta (Brotzen) in having fewer chambers and in lacking the carinate periphery.

\section{Gyroidinoides infracretacea (Morozova)}

(Plate 12, Figs. 1-3)

A persistent member of the Albian to Turonian fauna of Hole 585 and the late Aptian of Hole 585A, the specimens show variability in the convexity of the umbilical side and in the degree of peripheral roundness.

\section{Gyroidinoides nitidus (Reuss)}

(Plate 12, Figs. 6-8)

Small, rare, specimens recovered from the Coniacian-Santonian to Maestrichtian interval of Hole 585 and the Maestrichtian of Hole 585A are assigned to this species. Specimens show variation in the convexity of the umbilical side and the roundness of the periphery. The test shape and a broad apertural face identifies this species.

\section{Gyroidinoides subglobosus Dailey}

(Plate 12, Figs. 10-12)

Globular specimens with five inflated chambers in the final whorl, a flattened spiral side, and a broadly rounded periphery are assigned to this species. Specimens are rare in the Albian to Cenomanian interval of Hole 585 .
Lenticulina muensteri (Roemer)

(Plate 3, Figs. 21-22)

Specimens from the late Aptian interval of Hole 585A and the Cenomanian interval of Hole 585 are referred to this species on the basis of the thin biumbonate test with a carinate periphery, 7 to 10 chambers in the final whorl, and tangential, slightly curved sutures.

\section{Lingulina sp. \\ (Plate 4, Fig. 9)}

Several small specimens from the late Campanian of Hole 585 are elongate, palmate, compressed with an acute periphery, and have equitant chambers and oblique slightly depressed sutures.

\section{Neobulimina sp. \\ (Plate 4, Fig. 23)}

Several small, poorly preserved specimens from the Cenomanian to Coniacian-Santonian interval of Hole 585 have a triserial test that becomes biserial. Chambers are inflated and the test is ovate, circular in axial section, and slightly twisted. The aperture is a loop-shaped opening on the terminal face. These specimens differ from Neobulimina minima Tappan in the more ovate shape and somewhat higher chambers.

\section{Nodosaria? sp.}

(Plate 2, Fig. 9)

A single, poorly preserved and broken specimen has an elongate, hexagonal test, and apical spine. Sutures appear to be horizontal and the apertural characteristics are obscured. The specimens differ from Nodosaria prismatica Reuss in lacking the distinct, slightly inflated chambers.

\section{Planulina lundegreni Brotzen}

(Plate 7, Figs. 10-12, 16-18)

Test is discoidal and compressed, and its periphery is rounded. Spiral side is evolute with a small boss. Umbilical side is partially evolute and flat to slightly concave. Chambers 9 to 10 are within the final whorl. Sutures are thickened, raised, and strongly arcuate. The species is rare but persistent through the late Cenomanian to Coniacian-Santonian interval of Hole 585. It is also present in the Cenomanian-Turonian section of Hole 585A.

\section{Planulina sp.}

(Plate 7, Figs. 13-14, 19)

A single specimen from the late Cenomanian of Hole 585 is discoidal and compressed with a rounded periphery. It differs from Planulina lundegreni Brotzen in having a more compressed test, fewer, more inflated chambers, and gently curved, slightly depressed sutures.

\section{Pleurostomella obtusa Berthelin}

(Plate 8, Figs. 9-10)

Several poorly preserved specimens from the Albian to Cenomanian of Hole 585 and the Cenomanian-Turonian of Hole 585A are assigned to this species. The taxonomy used herein follows that of Bartenstein (1954) who placed Pleurostomella reussi Berthelin in synonomy with $P$. obtusa.

\section{Praebulimina aspera (Cushman and Parker)} (Plate 4, Fig. 20)

Test is elongate, gently tapering, with three slightly inflated chambers in the final whorl. A single specimen was recovered from the late Campanian of Hole 585.

\section{Praebulimina carseyae (Plummer)} (Plate 4, Fig. 21)

Test is ovate, with four chambers in the final whorl, each slightly inflated. The species is rare but persistent through the Coniacian-Santonian to Maestrichtian interval of Hole 585 and the Maestrichtian of Hole 585A. 


\section{Praebulimina cushmani (Sandidge)}

(Plate 4, Figs. 18-19)

Test is ovate, robust, with four inflated chambers in the last whorl. The species was found in the late Campanian to Maestrichtian interval of Hole 585.

\section{Praebulimina kickapooensis (Cole)} (Plate 5, Fig. 1)

Rare specimens from the Campanian to Maestrichtian interval of Hole 585 have an elongate, smooth test with three chambers in the final whorl.

\section{Praebulimina nannina (Tappan)}

(Plate 5, Figs. 2-3)

Test is small, flaring, triangular in longitudinal section, with three slightly inflated chambers in the final whorl. The small size and distinctly flaring test characterize this species. The species was recovered in the Albian to Cenomanian interval of Hole 585 and the Cenomanian-Turonian of Hole 585A.

\section{Praebulimina plana (Cushman and Parker)}

(Plate 5, Figs. 4-5)

Test is ovate, globular, with four inflated chambers in the final whorl that form more than half of the test. Specimens referred to this species, originally named as a variety of Praebulimina carseyae (Plummer), are rare but persistent in the late Campanian to Maestrichtian interval of Hole 585 .

\section{Praebulimina reussi (Morrow)}

(Plate 5, Fig. 6)

Test is ovate, with three very slightly inflated chambers in the final whorl. The species differs from Praebulimina nannina (Tappan) in being more ovate in outline, and in having a more widely flaring test. Junior synonyms include Bulimina ovulum Reuss and $B$. ventricosa Brotzen. The species is rare but persistent from the late Cenomanian to the Maestrichtian of Hole 585 .

\section{Praebulimina spinata (Cushman and Campbell) (Plate 5, Fig. 7)}

A single specimen from the late Campanian of Hole 585 has an apical spine and small spines on the initial chambers.

\section{Praebulimina taylorensis (Cushman and Parker)} (Plate 5, Fig. 8)

A single specimen from the late Campanian of Hole 585 shows the distinctive irregular costae characteristic of the species.

Praebulimina sp.

(Plate 5, Figs. 9-15)

Distinctive specimens from the Maestrichtian interval of Hole 585 have a small, flaring test consisting of 3 whorls with inflated chambers and 4 chambers in the final whorl. Each chamber in the final 2 whorls is extended into a single hollow spine that tends to curve toward the base of the test. Sutures are distinct and depressed. The aperture consists of a loop-shaped opening in the final chamber.

\section{Pyramidina pseudospinulosa (Troelson)}

$$
\text { (Plate 5, Fig. 16) }
$$

Specimens from the late Campanian to Maestrichtian interval show the characteristics of this species: flaring test with rounded margins, concave sides, and subtriangular axial section; sutures are distinct and curved; aperture is a high, loop-shaped opening at the base of the final chamber. The species was recovered from the late Campanian to Maestrichtian interval of Hole 585.

\section{Pyramidina rudita (Cushman and Parker)}

(Plate 5, Fig. 17)

The small size, more flaring and shorter test, and the hispid surface ornamentation differentiate this species from Pyramidina pseudospinulosa. Specimens were found in the late Campanian to Maestrichtian interval of Hole 585 .

\section{Pyramidina triangularis (Cushman and Parker)}

(Plate 5, Figs. 18-19)

This species is distinguished from specimens assigned to Pyramidina rudita by the smaller, less flaring test and smoother surface ornamentation. The species is a rare but persistent member of the late Campanian to Maestrichtian assemblage of Hole 585 .

\section{Serovaina orbicella (Bandy)}

(Plate 6, Figs. 19-21)

The globular, trochospiral test, with broadly rounded periphery, small umbilicus, 7 to 8 chambers in the final whorl, radial sutures, and interiomarginal aperture with an apertural lip, distinguishes this species. Rare species were found in the late Campanian to Maestrichtian interval of Hole 585 .

\section{Sigmomorphina sp. \\ (Plate 4, Figs. 12-14)}

Rare specimens from the Albian interval of Hole 585 are small, elongate, and compressed with a sharply rounded axial periphery. The chamber arrangement is sigmoid, and the sutures become slightly depressed. Surface ornamentation consists of longitudinal costae, and the aperture is terminal and radiate.

\section{Stilostomella pseudoscripta (Cushman) (Plate 6, Figs. 8-9)}

A persistent member of the Campanian to Maestrichtian fauna of Hole 585. Specimens have an elongate, gently tapering test with inflated chambers. The surface is finely spinose, and the aperture is terminal and rounded with a phialine lip. Variation is noted in the degree of chamber inflation and the degree of spinosity.

\section{Spiroplectammina roemeri Lalicker \\ (Plate 1, Figs. 4-5)}

Rare specimens were recovered from the late Cenomanian to Turonian interval of Hole 585. The species includes Spiroplectammina laevis cretosa Cushman as a junior synonym.

\section{Spiroplectinata complanata (Reuss)}

(Plate 1, Fig. 17)

A single specimen from the Cenomanian interval of Hole 585 is identified by the early, small triserial stage followed by a flattened biserial stage.

\section{Vaginulina recta Reuss \\ (Plate 4, Fig. 3)}

Several broken specimens from the Albian to Cenomanian interval of Hole 585 are assigned to this species on the basis of the flattened, straight test, rectangular axial outline, and distinct sutures.

\section{Vaginulina sp.}

(Plate 4, Figs. 4-5)

Two small, presumably juvenile specimens from the late Campanian of Hole 585 have a compressed test with a rectangular axial section. Both tests consist of a proloculus followed by a single, slightly inflated chamber ornamented with 5 to 8 fine costae.

\section{Valvulineria lenticula (Reuss) \\ (Plate 6, Figs. 13, 18, 23)}

Two specimens from the late Campanian interval of Hole 585 have a low trochospiral, flattened test with a rounded periphery, slightly inflated chambers in the final whorl, gently curved sutures, and a distinct apertural flap projecting over the umbilicus. The species includes the junior synonym Rotalina depressa Alth.

\section{Valvulineria loetterle (Tappan) \\ (Plate 7, Figs. 1-3)}

The trochospiral test with flattened spiral side, convex umbilical side, rounded periphery, and apertural flap characterizes this species. Specimens were found throughout the Aptian to Cenomanian interval of Hole 585 and the Cenomanian-Turonian of Hole 585A. The species includes the junior synonym Valvulineria gracillima ten Dam. 


\section{ACKNOWLEDGMENTS}

I am pleased to thank the Deep Sea Drilling Project for inviting me to participate on Leg 89 aboard the Glomar Challenger. The manuscript benefited from thoughtful reviews by John A. Barron and Charles D. Blome. I am indebted to R. L. Oscarson for operating the Cambridge scanning electron microscope, and to M. McGann for invaluable help in preparing the photomicrographs and illustrations. M. A. Rouse was particularly helpful in the many phases of manuscript and data preparation on the word processor.

In particular, I want to acknowledge the co-chiefs S. O. Schlanger and R. Moberly for working to maintain a cooperative and constructive atmosphere onboard ship and during subsequent meetings.

\section{REFERENCES}

Bartenstein, H., 1954. Revision von Berthelin's Mémoir 1880 über die Alb-Foraminiferen von Montcley. Senckenbergiana, 35:37-50.

Bartenstein, H., Bettenstaedt, F., and Bolli, H. M., 1966. Die Foraminiferen der Unterkreide von Trinidad, W. I. Zweiter Teil: MaridaleFormation (Typlokalität). Eclogae Geol. Helv., 59:129-177.

Bartenstein, H., and Bolli, H. M., 1973. Die Foraminiferen der Unterkreide von Trinidad, W. I. Dritter Teil: Maridaleformation (CoTyplokalität). Eclogae Geol. Helv., 66:386-418.

Brotzen, F., 1936. Foraminiferen aus dem schwedischen untersten Senon von Eriksdal in Schonen. Sver. Geol. Under. Ser C, 30(3, 396): 1-206.

de Wever, P., 1981. Spyrids, Artostrobiids, and Cretaceous radiolarians from the western Pacific, Deep Sea Drilling Project Leg 61. In Larson, R. L., Schlanger, S. O., et al., Init. Repts. DSDP, 61: Washington (U.S. Govt. Printing Office), 507-520.

Gawor-Biedowa, E., 1972. The Albian, Cenomanian, and Turonian foraminifers of Poland and their stratigraphic importance. Acta Palaeontol. Polonica, 17:1-155.

Hancock, J. M., 1975. The sequence of facies in the Upper Cretaceous of northern Europe compared with that of the Western Interior. Geol. Assoc. Canada, Spec. Paper, 13:83-118.

Heezen, B. C., MacGregor, I. D., et al., 1973. Init. Repts. DSDP, 20: Washington (U.S. Govt. Printing Office).

Hekel, H., 1973. Nannofossil biostratigraphy, Leg 20, Deep Sea Drilling Project. In Heezen, B. C., MacGregor, I. D., et al., Init. Repts. $D S D P, 20$ : Washington (U.S. Govt. Printing Office).

Hemleben, C., and Troester, J., 1984. Campanian-Maestrichtian deepwater foraminifers from Hole 543A Deep Sea Drilling Project. In Biju-Duval, B., Moore, J. C., et al., Init. Repts. DSDP, 78A: Washington (U.S. Govt. Printing Office), 509-532.

Hillebrandt, A., 1962. Das Paleozän und seine Foraminiferenfauna in Becken von Reichenhall und Salzburg. Abh. Bayer. Akad. Wiss. Math-Naturwiss. KI., 108:1-182.

Kauffman, F. G., 1973. Cretaceous Bivalvia. In Hallam, A. (Ed.), Atlas of Paleobiogeography: Amsterdam (Elsevier), pp. 353-383.

Krasheninnikov, V. A., and Hoskins, R. H., 1973. Late Cretaceous, Paleogene, and Neogene planktonic foraminifera. In Heezen, B. C., MacGregor, I. D., et al., Init. Repts. DSDP, 20: Washington (U.S. Govt. Printing Office), 105-203.

Larson, R. L., Moberly, R., et al., 1975. Init. Repts. DSDP, 32: Washington (U.S. Govt. Printing Office).

Malapris, M., 1965. Les Gavelinellidae et formes affines du gisement Albian de Courcelles (Aube). Rev. Micropaleontol., 8:131-150.

Medizza, F., 1969. I generi Bolivinoides, Aragonia, e Neoflabellina (Foraminifera) nelle formazione cretaceo-eoceniche del Veneto. Inst. Geol. Mineral. Univ. Padova, 26:1-44.

Price, R. J., 1977. The evolutionary interpretation of the Foraminiferida Arenobulimina, Gavelinella, and Hedbergella in the Albian of north-west Europe. Palaeontology, 20:503-527.

Schlanger, S. O., Jackson, E. D., et al., 1976. Init. Repts. DSDP, 33: Washington (U.S. Govt. Printing Office).

Schlanger, S. O., and Premoli Silva, I., 1981. Tectonic, volcanic, and paleogeographic implications of redeposited reef faunas of Late Cretaceous and Tertiary age from the Nauru Basin and the Line Islands. In Larson, R. L., Schlanger, S. O., et al., Init. Repts. DSDP, 61: Washington (U.S. Govt. Printing Office), 817-827.

Sliter, W. V., 1968. Upper Cretaceous foraminifera from Southern California and northwestern Baja California, Mexico. Univ. Kans. Paleontol. Contrib., 49(art. 7):1-141.
1980. Mesozoic foraminifers and deep-sea benthic environments from Deep Sea Drilling Project Sites 415 and 416, eastern North Atlantic. In Lancelot, Y., Winterer, E. L., et al., Init. Repts. DSDP, 50: Washington (U.S. Govt. Printing Office), 348-353. 1984. Foraminifers from Cretaceous limestone in the Franciscan Complex, northern California. In Blake, M. C., Jr. (Ed.), Franciscan Geology of Northern California. Pacific Section Soc. Econ. Paleontol. Mineral., 43:149-162.

Thiede, J., Dean, W. E., Rea, D. K., Vallier, T. L., and Adelseck, C. G., 1981. The geologic history of the Mid-Pacific Mountains in the central North Pacific Ocean-a synthesis of deep-sea drilling studies. In Thiede, J., Vallier, T. L., et al., Init. Repts. DSDP, 62: Washington (U.S. Govt. Printing Office), 1073-1120.

Thiede, J., Vallier, T. L., et al., 1981. Init. Repts. DSDP, 62: Washington (U.S. Govt. Printing Office).

Vail, P. R., Mitchum, R. M., Jr., and Thompson, S., 1977. Seismic stratigraphy and global changes of sea level. Part 4: Global cycles of relative changes of sea level. In Payton, C. E. (Ed.), Seismic Stratigraphy-Applications to Hydrocarbon Exploration. Am. Assoc. Pet. Geol. Mem., 26:83-97.

Winterer, E. L., Ewing, J. I., et al., 1973. Init. Repts. DSDP, 17: Washington (U.S. Govt. Printing Office).

Date of Initial Receipt: 15 November 1984

Date of Acceptance: 19 February 1985

\section{APPENDIX A \\ Faunal Reference List}

Alabamina dorsoplana $($ Brotzen $)=$ Eponides dorsoplana Brotzen Allomorphina halli Jennings

Aragonia ouezzanensis $($ Rey) $=$ Bolivinoides ouezzanensis Rey

A. trinitatensis (Cushman and Jarvis) $=$ Bolivinoides trinitatensis Cushman and Jarvis

A. velascoensis (Cushman) $=$ Textularia velascoensis Cushman Astacolus complanatus (Reuss) = Cristellaria complanata Reuss

A. excentricus $($ Cornuel $)=$ Cristellaria excentrica Cornuel

A. gratus (Reuss) = Cristellaria grata Reuss

A. incurvatus (Reuss) $=$ Cristellaria incurvata Reuss

A. planiusculus (Reuss) = Cristellaria planiuscula Reuss

A. scitulus (Berthelin) $=$ Cristellaria scitula Berthelin

Bolivina sp. 1

Bolivina sp. 2

Bolivinoides laevigatus Marie

Cassidella tegulata (Reuss) = Virgulina tegulata Reuss

Charltonina sp. cf. C. meeterenae (Visser) = Pseudoparella meeterenae Visser

Cibicides ribbingi Brotzen

C. voltziana (d'Orbigny) = Rotalina voltziana d'Orbigny

Conicospirillina sp.

Conorbina sp. cf. C. marginata Brotzen

Conorboides sp.

Coryphostoma sp. cf. C. minutissimum (Cushman) = Loxostomum minutissimum Cushman

Coryphostoma plaitum $($ Carsey) $=$ Bolivina plaita $($ Carsey)

C. reussi $($ Geinitz $)=$ Virgulina reussi Geinitz

C. sp.

Dentalina communis d'Orbigny

D. cylindroides Reuss

D. distincta Reuss

D. gracilis d'Orbigny

D. sp. cf. D. involvens Cushman

D. marcki Reuss

D. nana (Reuss) $=$ Nodosaria (Dentalina) nana Reuss

D. oligostegia Reuss

D. soluta Reuss

D. vistulae Pozaryska

Dorothia conula (Berthelin) $=$ Textularia conulus Reuss

Dorothia filiformis (Berthelin) = Gaudryina filiformis Berthelin

D. oxycona (Reuss) = Gaudryina oxycona Reuss

Ellipsoidella coalingensis (Cushman and Church) $=$ Nodosarella coa lingensis Cushman and Church

E. gracillima $($ Cushman $)=$ Nodosarella gracillima Cushman 
E. kugleri $($ Cushman and Renz $)=$ Nodosarella kugleri Cushman and Renz

Ellipsodimorphina sp. 1

E. sp. 2

Eoguttulina anglica Cushman and Ozawa

Eouvigerina hispida Cushman

Epistomina chapmani ten Dam

E. reticulata (Reuss) $=$ Rotalia reticulata Reuss

E. spinulifera (Reuss) $=$ Rotalia spinulifera Reuss

Fissurina alata Reuss

Frondicularia sp. cf. F. verneuiliana d'Orbigny

Fursenkoina nederi Sliter

Gaudryina austinana $($ Cushman $)=$ Gaudryina $($ Siphogaudryina $)$ austinana Cushman

G. cushmani Tappan

G. dividens Grabert

G. laevigata Franke

$G$. reicheli Bartenstein, Bettenstaedt and Bolli

Gavelinella sp. cf. G. ammonoides (Reuss) = Rosalina ammonoides Reuss

G. barremiana bizouardae Maync

G. belorussica $($ Akimez) $=$ Anomalina $($ Brotzenella $)$ belorussica Akimez

G. sp. cf. G. bembix (Marsson) = Discorbis bembix Marsson

G. cayeuxi mangshalakensis $($ Vassilenko) $=$ Anomalina $(P$ seudovalvulineria) cayeuxi mangshalakensis Vassilenko

G. cenomanica $($ Brotzen) $=$ Cibicidoides (Cibicides) cenomanica Brotzen

G. intermedia $($ Berthelin) = Anomalina intermedia Berthelin

Gavelinella nacatochensis $($ Cushman $)=$ Planulina nacatochensis Cushman

G. rudis (Reuss) $=$ Rosalina rudis Reuss

G. sandidgei $($ Brotzen $)=$ Cibicides sandidgei Brotzen

G. whitei $($ Martin $)=$ Anomalina whitei Martin

G. sp.

Globorotalites michelianus (d'Orbigny) $=$ Rotalina michelianus d'Orbigny

G. tappanae Sliter

G. sp.

Globulina lacrima (Reuss) $=$ Polymorphina (Globulina) lacrima Reuss

Gyroidinoides beisseli $($ Schijfsma $)=$ Eponides beisseli Schijfsma

G. infracretaceus (Morozova) $=$ Gyroidina nitida Reuss var. infracretacea Morozova

G. megastomus (Grzybowski) = Pulvinulina megastoma Grzybowski

G. nitidus (Reuss) $=$ Rotalina nitida Reuss

G. subglobosus Dailey

Lagena apiculata Reuss

L. elongata $($ Ehrenberg $)=$ Miliola $($ Ovulina $)$ elongata Ehrenberg

L. globosa (Montagu) = Vermiculum globosum Montagu

L. grahami Sliter

L. paucicosta Franke

L. sp. cf. L. plumigera Brady

L. substriata Williamson

L. sulcata $($ Walker and Jacob) $=$ Serpula $($ Lagena $)$ sulcata Walker and Jacob

Lenticulina acuta (Reuss) $=$ Cristellaria acuta Reuss

L. comptoni (Sowerby) $=$ Nautilus comptoni Sowerby

L. gaultina $($ Berthelin $)=$ Cristellaria gaultina Berthelin

L. muensteri $($ Roemer) $=$ Robulus münsteri Roemer

L. pulchella (Reuss) $=$ Cristellaria pulchella Reuss

L. saxocretacea Bartenstein

Lingulina nodosaria Reuss

L. sp.

Loxostomum eleyi $($ Cushman $)=$ Bolivinita eleyi Cushman

Marginulinopsis cephalotes (Reuss) = Cristellaria cephalotes Reuss

Neobulimina canadensis Cushman and Wickenden

N. sp.

Nodosaria aspera Reuss

N. obscura Reuss
N. proboscidea Reuss

N.? sp.

Nonionella robusta Plummer

Nuttallinella florealis $($ White $)=$ Gyroidina florealis White

Orithostella pazdroae (Gawor-Biedowa) = Lingulogavelinella pazdroae Gawor-Biedowa

Osangularia cordieriana (d'Orbigny) $=$ Rotalina cordieriana d'Orbigny

O. navarroana $($ Cushman $)=$ Pulvinulinella navarroana Cushman

O. schloenbachi (Reuss) $=$ Rotalia schloenbachi Reuss

O. whitei $($ Brotzen $)=$ Eponides whitei Brotzen

Patellina subcretacea Cushman and Alexander

Planulina lundegreni Brotzen

P. sp.

Pleurostomella obtusa Berthelin

P. subnodosa Reuss

P. zuberi Grzybowski

Praebulimina aspera (Cushman and Parker)

P. carseyae (Plummer) $=$ Buliminella carseyae Plummer

P. cushmani (Sandidge) $=$ Buliminella cushmani Sandidge

P. kickapooensis $($ Cole $)=$ Bulimina kickapooensis Cole

$P$. nannina $($ Tappan $)=$ Bulimina nannina Tappan

P. plana $($ Cushman and Parker $)=$ Buliminella carseyae Plummer var. plana Cushman and Parker

P. reussi $($ Morrow $)=$ Bulimina reussi Morrow

P. spinata $($ Cushman and Campbell) $=$ Bulimina spinata Cushman and Campbell

P. taylorensis (Cushman and Parker) $=$ Bulimina taylorensis Cushman and Parker

$P$ sp.

Psuedopatellinella minuta Sliter

Psuedospiroplectinata compressiuscula $($ Chapman $)=$ Bigenerina compressiuscula Chapman

Pullenia minuta Cushman

Pyramidina pseudospinulosa (Troelsen) = Reussella pseudospinulosa Troelsen

P. rudita (Cushman and Parker) $=$ Bulimina rudita Cushman and Parker

P. triangularis $($ Cushman and Parker) $=$ Bulimina triangularis (Cushman and Parker)

Pyrulina cylindroides $($ Roemer $)=$ Polymorphina cylindroides Roemer

P. velascoensis $($ Cushman) $=$ Polymorphina velascoensis Cushman

Quadrimorphina allomorphinoides (Reuss) $=$ Valvulineria allomorphinoides Reuss

Ramulina aculeata (d'Orbigny) = Dentalina aculeata d'Orbigny

Reussella szajnochae (Grzybowski) = Verneuilina szajnochae Grzybowski

Saracenaria navicula (d'Orbigny) $=$ Cristellaria navicula d'Orbigny

$S$. triangularis (d'Orbigny) = Cristellaria triangularis (d'Orbigny)

Serovaina orbicella (Bandy) $=$ Gyroidina orbicella $($ Hagenow) var. or bicella Bandy

Sigmomorphina sp.

Spiroplectammina chicoana Lalicker

S. dentata $($ Alth $)=$ Textularia dentata Alth

$S$, roemeri Lalicker

Spiroplectinata annectens (Parker and Jones) $=$ Textularia annectens Parker and Jones

$S$. complanata (Reuss) $=$ Proroporus complanatus Reuss

Stilostomella pseudoscripta $($ Cushman $)=$ Ellipsonodosaria pseudoscripta Cushman

Textularia washitensis Carsey

Tritaxia aspera $($ Cushman $)=$ Clavulina trilatera Cushman var. aspera Cushman

T. pyramidata Reuss

T. tricarinata Reuss

Vaginulina recta Reuss

V. sp.

Vaginulinopsis ensis Reuss $=$ Marginulina ensis Reuss

Valvulineria lenticula (Reuss) = Rotalina lenticula Reuss

V. loetterle $($ Tappan $)=$ Gyroidina loetterle Tappan 
APPENDIX B

Samples Barren of Allochthonous Benthic Foraminifers from Holes 585 and $585 \mathrm{~A}$

\begin{tabular}{lll}
\multicolumn{1}{c}{ Sample } & \multicolumn{1}{c}{ Sample } & \multicolumn{1}{c}{ Sample } \\
\hline $585-17-1,4-7$ & $585-34-2,77-79$ & $585-54, C C(2-5)$ \\
$585-17-2,38-40$ & $585-34-3,9-11$ & $585-55-1,114-116$ \\
$585-18-1,110-114$ & $585-35-1,80-82$ & $585-55-2,102-105$ \\
$585-18-1,130-133$ & $585-36-1,83-84$ & $585 \mathrm{~A}-3-1,143-145$ \\
$585-19-1,23-25$ & $585-38-1,65-66$ & $585 \mathrm{~A}-5, \mathrm{CC}(19-21)$ \\
$585-19-1,52-54$ & $585-39, \mathrm{CC}(0-5)$ & $585 \mathrm{~A}-7-1,82-89$ \\
$585-20-2,80-82$ & $585-39, \mathrm{CC}(29-30)$ & $585 \mathrm{~A}-8-2,141-145$ \\
$585-20-3,146-148$ & $585-40-1,32-33$ & $585 \mathrm{~A}-8-3,67-69$ \\
$585-20-4,8-10$ & $585-41, \mathrm{CC}$ & $585 \mathrm{~A}-8, \mathrm{CC}(14-18)$ \\
$585-20-4,31-33$ & $585-42-1,68$ & $585 \mathrm{~A}-10-1,7-8$ \\
$585-21-1,34-36$ & $585-42-3,135-137$ & $585 \mathrm{~A}-10-1,34-35$ \\
$585-26-1,23-25$ & $585-43-1,120-123$ & $585 \mathrm{~A}-12-3,37-39$ \\
$585-26-1,43-45$ & $585-45-1,48-50$ & $585 \mathrm{~A}-12-4,5-7$ \\
$585-26-1,47-49$ & $585-45-1,86-88$ & $585 \mathrm{~A}-13-1,14-16$ \\
$585-27-1,111-112$ & $585-45-2,24-26$ & $585 \mathrm{~A}-13-3,62-64$ \\
$585-27-3,123-127$ & $585-45-2,115-117$ & $585 \mathrm{~A}-14-3,22-24$ \\
$585-27-4,45-47$ & $585-45, \mathrm{CC}$ & $585 \mathrm{~A}-15-3,90-92$ \\
$585-27, \mathrm{CC}$ & $585-46-2,18-20$ & $585 \mathrm{~A}-16-1,3-5$ \\
$585-28-1,19-21$ & $585-47-3,108-110$ & $585 \mathrm{~A}-16-2,32-33$ \\
$585-28-3,51-53$ & $585-48-2,125-127$ & $585 \mathrm{~A}-16-3,13-15$ \\
$585-28-4,140-142$ & $585-48, \mathrm{CC}$ & $585 \mathrm{~A}-16-4,64-66$ \\
$585-30, \mathrm{CC}(7-9)$ & $585-49-1,115-117$ & $585 \mathrm{~A}-17, \mathrm{CC}(9-12)$ \\
$585-31-1,139-142$ & $585-49-5,116-119$ & $585 \mathrm{~A}-18-2,90-93$ \\
$585-31-2,80-82$ & $585-50-3,80-82$ & $585 \mathrm{~A}-19, \mathrm{CC}(4-6)$ \\
$585-32-2,31-34$ & $585-51-2,37-39$ & $585 \mathrm{~A}-20-3,4-6$ \\
$585-32-2,138-141$ & $585-52-1,118-119$ & $585 \mathrm{~A}-20-3,28-30$ \\
$585-32-3,29-33$ & $585-52-3,91-93$ & $585 \mathrm{~A}-20-3,48-50$ \\
$585-32-3,72-75$ & $585-54-3,0-3$ & $585 \mathrm{~A}-21-1,38-40$ \\
\hline & & \\
\hline & &
\end{tabular}

Note: Samples indicate hole-core-section, interval in $\mathrm{cm}$. 


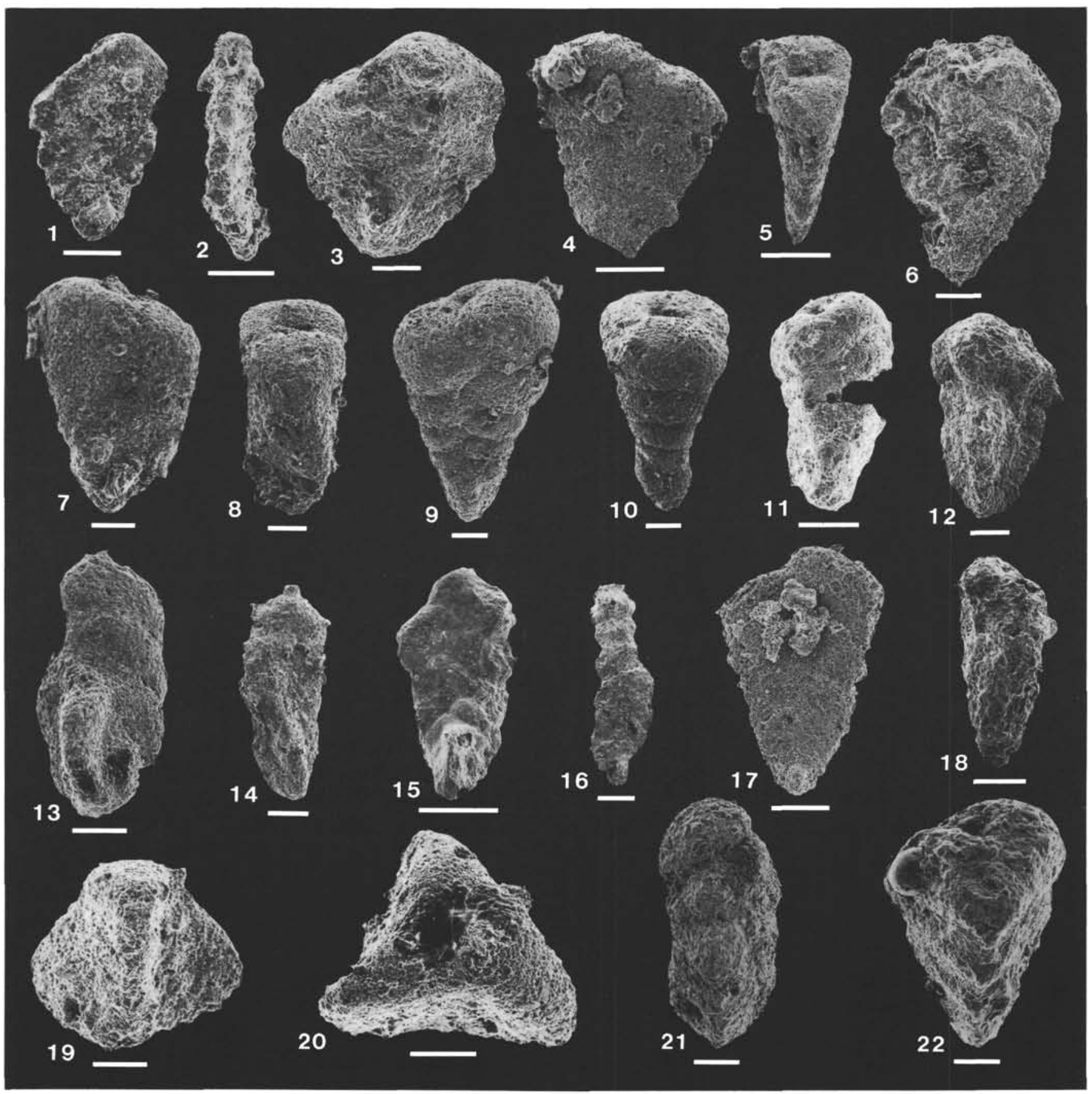

Plate 1. 1-2. Spiroplectammina chicoana Lalicker, side and edge views (scale bar $=100 \mu \mathrm{m}$ ), Sample 585-18-2, 23-27 cm. 3. Spiroplectammina dentata (Alth) $(50 \mu \mathrm{m})$, Sample 585-20-3, 52-53 cm. 4-5. Spiroplectammina roemeri Lalicker, side and edge views ( $100 \mu \mathrm{m})$, Sample 585-32-4, $97-99 \mathrm{~cm}$. 6. Textularia washitensis Carsey $(60 \mu \mathrm{m})$, Sample $585-42, \mathrm{CC}(13-15 \mathrm{~cm}) . \quad 7-8$. Gaudryina austinana (Cushman), side and edge views $(50 \mu \mathrm{m})$, Sample 585-32-4, 97-99 cm. 9-10. Gaudryina cushmani Tappan, side and edge views (50 $\mu \mathrm{m})$, Sample 585-32-4, 97-99 cm. 11. Gaudryina laevigata Franke, side view of damaged specimen $(50 \mu \mathrm{m})$, Sample $585-20-3,52-53 \mathrm{~cm}$. 12. Gaudryina dividens Grabert (100 $\mu \mathrm{m})$, Sample 585-42,CC (13-15 cm). 13-14. Pseudospiroplectinata compressiuscula (Chapman) $(80 \mu \mathrm{m})$, Sample 585-32-4, 97-99 cm. 15-16. Spiroplectinata annectens (Parker and Jones) $(150 \mu \mathrm{m}),(15)$ Sample 585-51-3, 54-56 cm, (16) specimen with uniserial stage, Sample 585-42,CC $(13-15 \mathrm{~cm})$. 17. Spiroplectinata complanata (Reuss) $(80 \mu \mathrm{m})$, Sample $585-32-4,97-99 \mathrm{~cm}$. 18. Gaudryina reicheli Bartenstein, Bettenstaedt, and Bolli $(80 \mu \mathrm{m})$, Sample 585-51-3, 54-56 cm. 19-20. Tritaxia tricarinata Reuss, side and apertural views $(50 \mu \mathrm{m})$, Sample 585-20-3, 52-53 cm. 21. Tritaxia aspera (Cushman) $(100 \mu \mathrm{m})$, Sample $585-42, \mathrm{CC}(13-15 \mathrm{~cm}) .22$. Tritaxia pyramidata Reuss $(100 \mu \mathrm{m})$, Sample $585-51-3,54-56 \mathrm{~cm}$. 


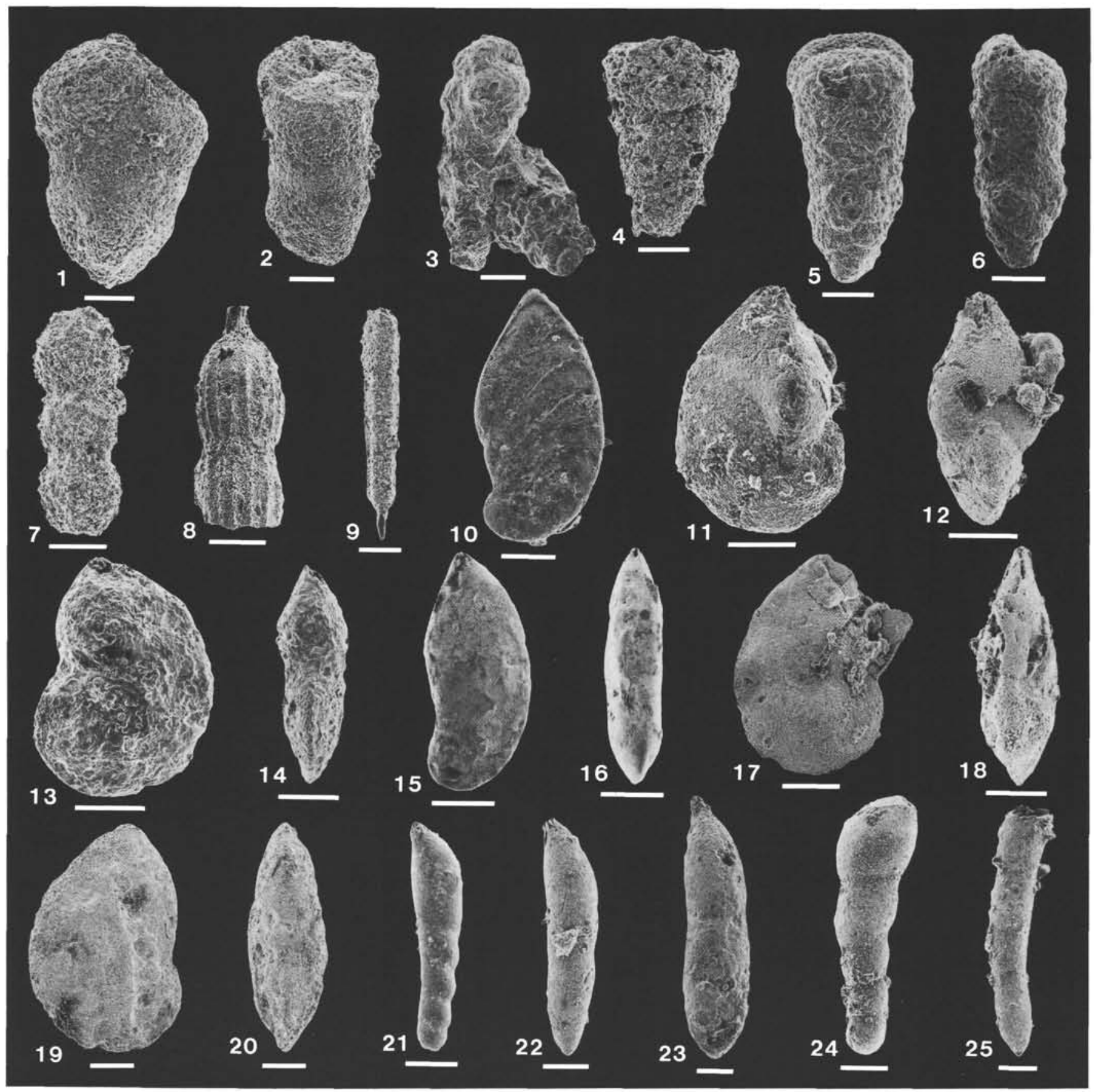

Plate 2. 1-2. Dorothia cornula (Reuss), side and edge views $(50 \mu \mathrm{m})$, Sample $585-32-4,97-99 \mathrm{~cm}$. 3. Dorothia filiformis (Berthelin) (100 $\mu \mathrm{m})$, Sample 585-51-3, 54-56 cm. 4-6. Dorothia oxycona (Reuss) $(80 \mu \mathrm{m})$, (4) Sample 585-29-2, 46-48 cm, (5-6) Sample 585-51-3, 54-56 cm. 7. Nodosaria aspera Reuss $(100 \mu \mathrm{m})$, Sample 585-32-3, 24-27 cm. 8. Nodosaria proboscidea Reuss $(50 \mu \mathrm{m})$, Sample 585-20-3, 52-53 cm. 9. Nodosaria? sp. $(50 \mu \mathrm{m})$, Sample $585-32-3,24-27 \mathrm{~cm}$. 10. Astacolus complanatus (Reuss) $(50 \mu \mathrm{m})$, Sample $585-32-4,97-99 \mathrm{~cm}$. 11-12, 1718. Astacolus excentricus (Cornuel) $(80 \mu \mathrm{m})$, Sample 585-32-4, 97-99 cm, (11-12) side and edge views, (17-18) side and edge views of less involute specimen. 13-14. Astacolus gratus (Reuss), side and edge views $(100 \mu \mathrm{m})$, Sample $585-41, \mathrm{CC} .15-16$. Astacolus incurvatus (Reuss), side and edge views $(200 \mu \mathrm{m})$, Sample 585-11-5, 43-45 cm. 19-20. Astacolus planiusculus (Reuss), side and edge views $(100 \mu \mathrm{m})$, Sample $585-42, \mathrm{CC}$ $(13-15 \mathrm{~cm})$. 21-22. Dentalina communis d'Orbigny $(100 \mu \mathrm{m}),(21)$ Sample $585-18-2,23-27 \mathrm{~cm}$, (22) Sample 585-32-3, 24-27 cm. 23. Dentalina cylindroides Reuss $(100 \mu \mathrm{m})$, Sample $585-42, C C(13-15 \mathrm{~cm})$. 24. Dentalina distincta Reuss $(80 \mu \mathrm{m})$, Sample $585-32-4,97-99 \mathrm{~cm} \quad 25$. Dentalina gracilis d'Orbigny $(100 \mu \mathrm{m})$, Sample $585-32-4,97-99 \mathrm{~cm}$. 


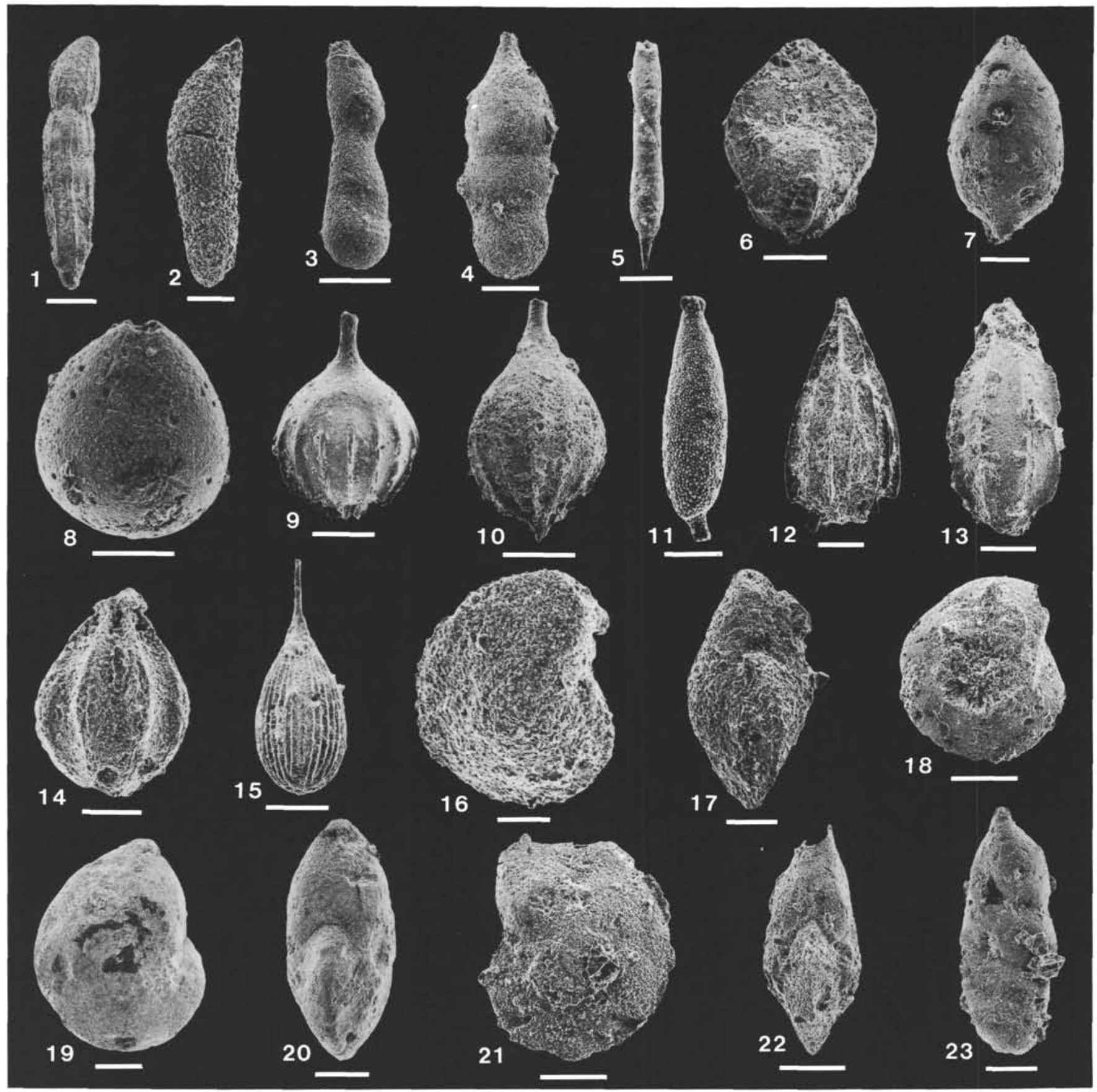

Plate 3. 1. Dentalina marcki Reuss $(80 \mu \mathrm{m})$, Sample $585-20-3,52-53 \mathrm{~cm}$. 2. Dentalina nana (Reuss) $(50 \mu \mathrm{m})$, Sample $585-32-3,24-27 \mathrm{~cm}$. 3. Dentalina oligostegia Reuss $(80 \mu \mathrm{m})$, Sample $585-20-3,52-53 \mathrm{~cm}$. 4. Dentalina soluta Reuss $(80 \mu \mathrm{m})$, Sample $585-32-4,97-99 \mathrm{~cm}$. 5. Dentalina vistulae Pozaryska $(100 \mu \mathrm{m})$, Sample $585-20-3,52-53 \mathrm{~cm}$. 6. Frondicularia $\mathrm{sp}$. cf. F. verneuiliana d'Orbigny $(100 \mu \mathrm{m})$, Sample $585-20-3,52-$ $53 \mathrm{~cm}$. 7. Lagena apiculata Reuss $(100 \mu \mathrm{m})$, Sample $585-20-3,52-53 \mathrm{~cm}$. 8. Lagena globosa (Montagu) $(80 \mu \mathrm{m})$, Sample $585-32-4,97-99 \mathrm{~cm}$. 910. Lagena grahami Sliter $(80 \mu \mathrm{m})$, (9) Sample $585-18-2,23-27 \mathrm{~cm}$, (10) Sample $585-20-3,52-53 \mathrm{~cm}$. 11. Lagena elongata (Ehrenberg) $(40 \mu \mathrm{m})$, Sample 585A-3-1, 128-130 cm. 12. Lagena sp. cf. L. plumigera Brady $(50 \mu \mathrm{m})$, Sample $585-20-3,52-53 \mathrm{~cm}$. 13. Lagena paucicosta Franke (80 $\mu \mathrm{m})$, Sample 585-20-3, 52-53 cm. 14. Lagena sulcata (Walker and Jacob) $(50 \mu \mathrm{m})$, Sample $585-32-3,24-27 \mathrm{~cm}$. 15. Lagena substriata Williamson $(80 \mu \mathrm{m})$, Sample 585-20-3, 52-53 cm. 16-18. Lenticulina comptoni (Sowerby), (16-17) side and edge views $(50 \mu \mathrm{m})$, Sample 585-32-3, $24-27 \mathrm{~cm},(18)$ side view $(80 \mu \mathrm{m})$, Sample $585-20-3,52-53 \mathrm{~cm} . \quad 19-20$. Lenticulina gaultina (Berthelin), side and edge views (150 $\mu \mathrm{m})$, Sample 585A-11-2, 96-99 cm. 21-22. Lenticulina muensteri (Roemer), side and edge views ( $80 \mu \mathrm{m})$, Sample 585-32-4, 97-99 cm. 23. Marginulinopsis cephalotes (Reuss) $(80 \mu \mathrm{m})$, Sample $585-32-4,97-99 \mathrm{~cm}$. 


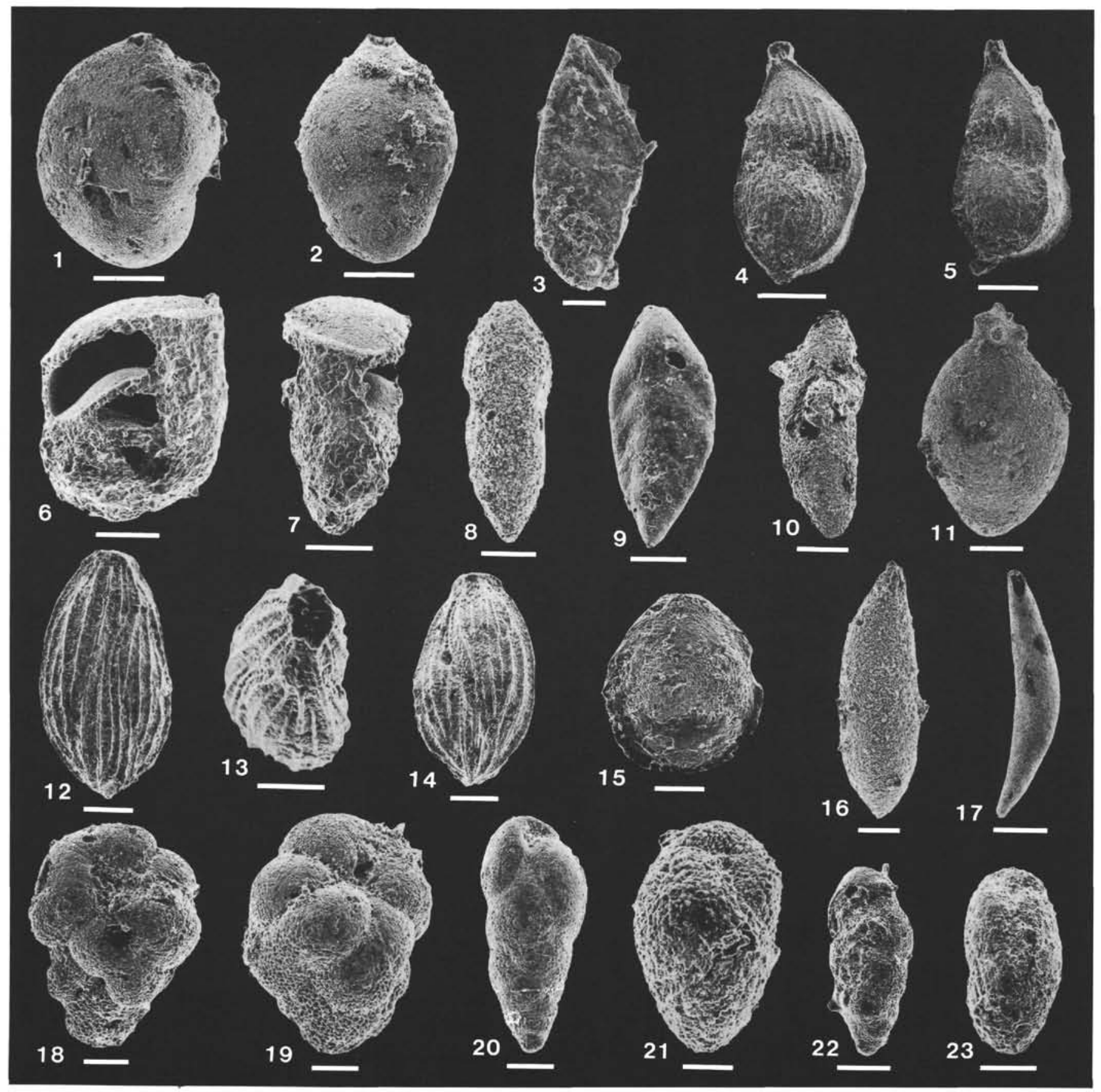

Plate 4. 1-2. Saracenaria triangularis (d'Orbigny), side and edge views $(80 \mu \mathrm{m})$, Sample $585-32-4,97-99 \mathrm{~cm}$. 3. Vaginulina recta Reuss (100 $\mu \mathrm{m})$, Sample 585-51-3, 54-56 cm. 4-5. Vaginulina sp. $(80 \mu \mathrm{m})$, Sample 585-20-3, 52-53 cm. 6-7. Vaginulinopsis ensis (Reuss), side and edge views $(70 \mu \mathrm{m})$, Sample 585-41,CC. 8. Lingulina nodosaria Reuss $(50 \mu \mathrm{m})$, Sample 585-32-3, 24-27 cm. 9. Lingulina sp. (40 $\mu \mathrm{m})$, Sample 585-20-3, $52-53 \mathrm{~cm}$. 10. Eoguttulina anglica Cushman and Ozawa $(100 \mu \mathrm{m})$, Sample 585A-9-1, 32-34 cm. 11. Globulina lacrima (Reuss) $(80 \mu \mathrm{m})$, Sample 585-32-4, 97-99 cm. 12-14. Sigmomorphina sp. side and apertural views $(50 \mu \mathrm{m})$, Sample $585-49-6,53-55 \mathrm{~cm}$. 15. Fissurina alata Reuss $(50 \mu \mathrm{m})$, Sample $585-18-2,23-27 \mathrm{~cm}$. 16. Pyrulina cylindroides (Roemer) $(50 \mu \mathrm{m})$, Sample $585-32-4,97-99 \mathrm{~cm} . \quad 17$. Pyrulina velascoensis (Cushman) $(150 \mu \mathrm{m})$, Sample 585-18-2, 23-27 cm. 18-19. Praebulimina cushmani (Sandidge) $(50 \mu \mathrm{m})$, Sample 585-20-3, 52-53 cm. 20. Praebulimina aspera (Cushman and Parker) $(50 \mu \mathrm{m})$, Sample 585-20-3, 52-53 cm. 21. Praebulimina carseyae (Plummer) $(30 \mu \mathrm{m})$, Sample 585-29-2, $46-48 \mathrm{~cm}$. 22. Neobulimina canadensis Cushman and Wickenden $(50 \mu \mathrm{m})$, Sample $585-20-3,52-53 \mathrm{~cm}$. 23. Neobulimina sp. (50 $\mu \mathrm{m})$, Sample $585-32-4,97-99 \mathrm{~cm}$. 


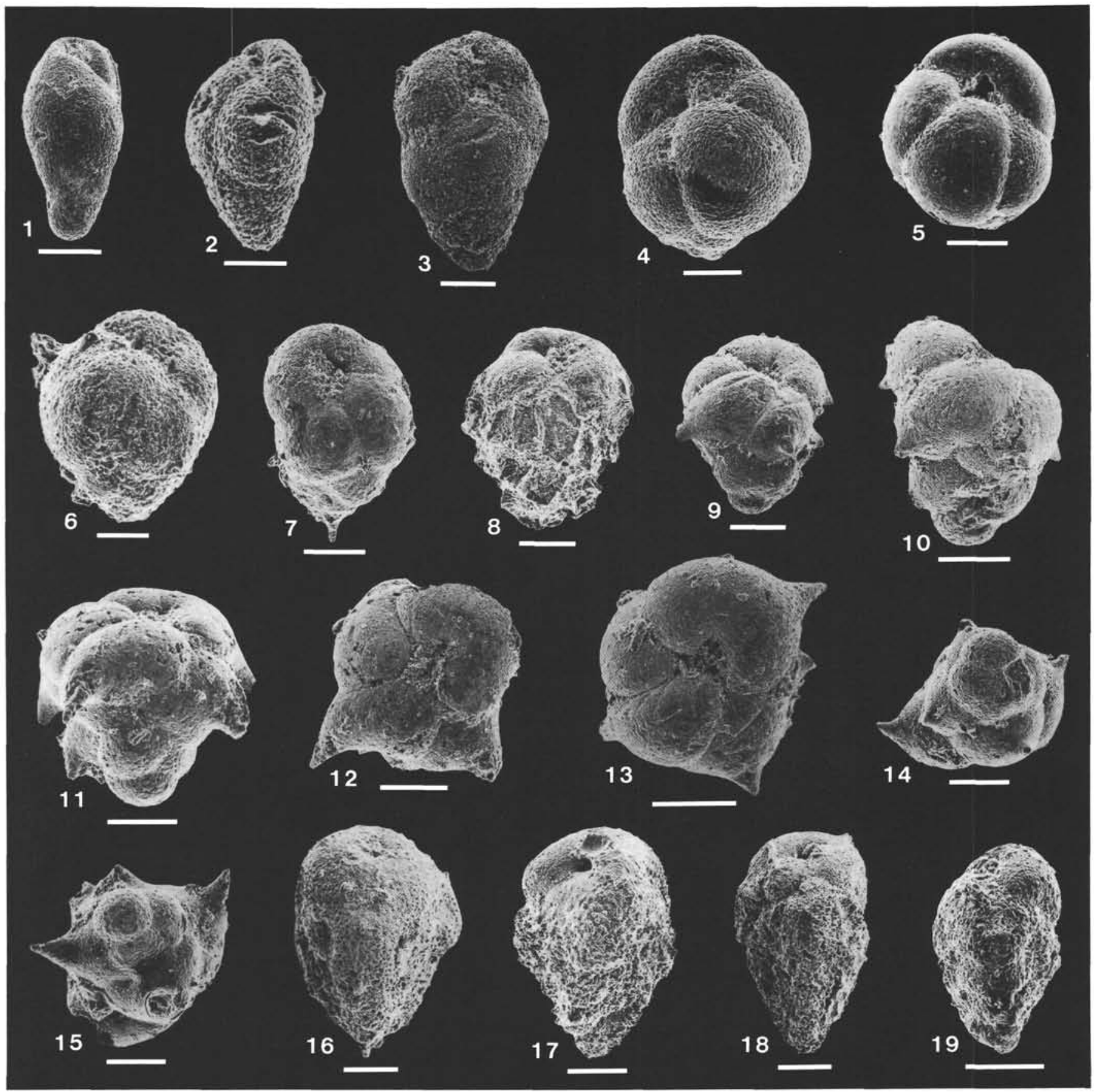

Plate 5. 1. Praebulimina kickapooensis (Cole) $(70 \mu \mathrm{m})$, Sample $585-20-3,52-53 \mathrm{~cm} . \quad 2-3$. Praebulimina nannina (Tappan) $(40 \mu \mathrm{m}),(2)$ Sample 585-32-3, 24-27 cm, (3) Sample 585A-9-1, 32-34 cm. 4-5. Praebulimina plana (Cushman and Parker) (50 $\mu \mathrm{m}),(4)$ Sample 585-20-3, 52-53 cm, (5) Sample 585-18-2, 23-27 cm. 6. Praebulimina reussi (Morrow) $(30 \mu \mathrm{m})$, Sample 585-32-3, 24-27 cm. 7. Praebulimina spinata (Cushman and Campbell) $(70 \mu \mathrm{m})$, Sample 585-20-3, 52-53 cm. 8. Praebulimina taylorensis (Cushman and Parker) $(50 \mu \mathrm{m})$, Sample 585-20-3, 52-53 cm. 915. Praebulimina sp. $(70 \mu \mathrm{m})$, Sample $585-20-3,52-53 \mathrm{~cm},(9,10,13)$ front, side, and apertural views, $(11,12,15)$ front, apertural, and apical views, (14) apical view of third specimen. 16. Pyramidina pseudospinulosa (Troelsen) $(70 \mu \mathrm{m})$, Sample 585-20-3, 52-53 cm. 17. Pyramidina rudita (Cushman and Parker) $(60 \mu \mathrm{m})$, Sample $585-20-3,52-53 \mathrm{~cm}$. 18-19. Pyramidina triangularis (Cushman and Parker) $(50 \mu \mathrm{m}),(18)$ Sample 585-20-3, 52-53 cm, (19) Sample 585-18-2, 22-27 cm. 


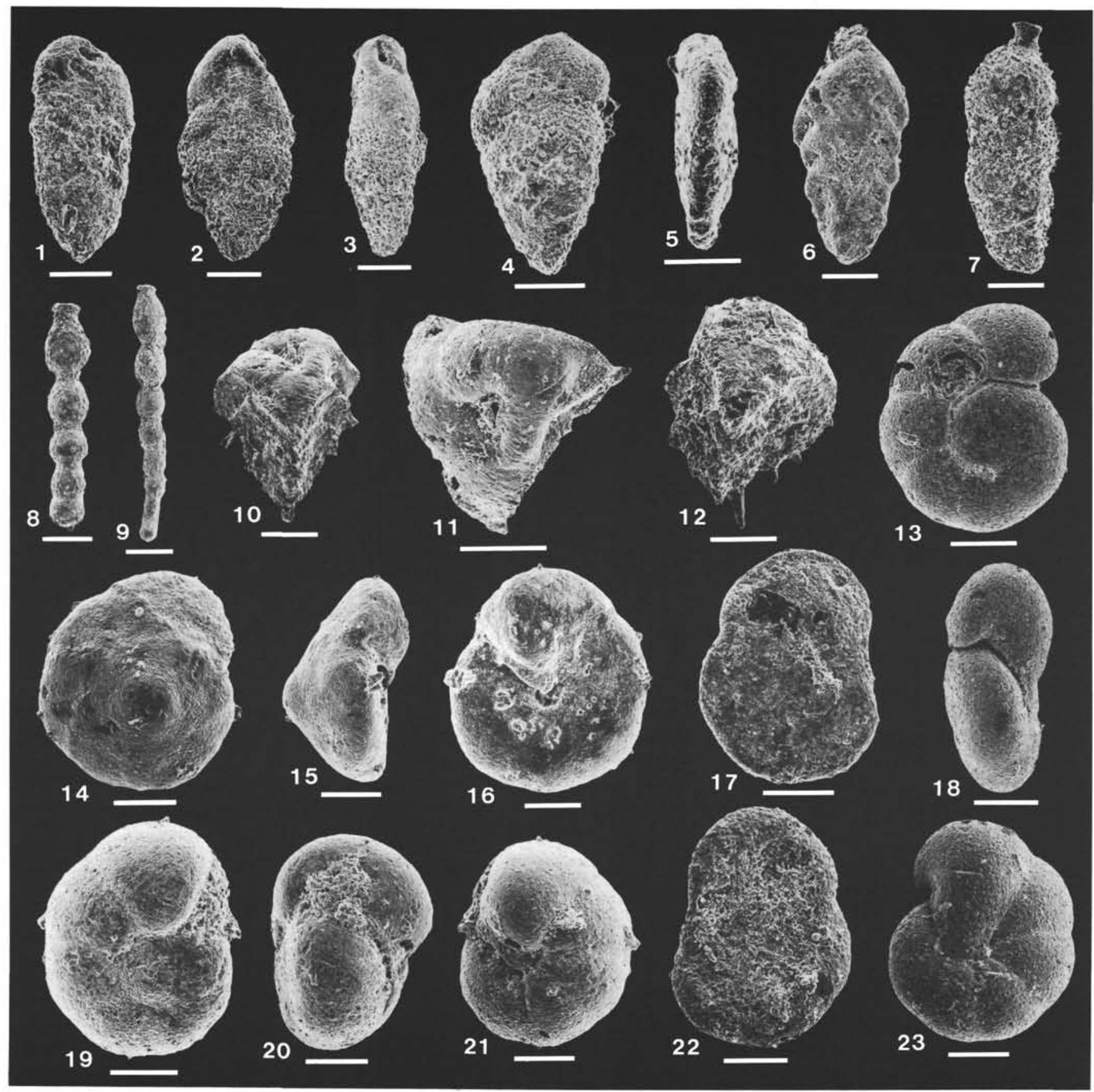

Plate 6. 1-3. Bolivina sp. 1. $(60 \mu \mathrm{m})$, (1) Sample 585-29-2, 46-48 cm, (2-3) side and edge views, Sample 585-29-2, 23-27 cm. 4-5. Bolivina sp. 2, side and edge views $(60 \mu \mathrm{m})$, Sample $585-29-2,46-48 \mathrm{~cm}$. 6. Bolivinoides laevigatus Marie $(60 \mu \mathrm{m})$, Sample $585-20-3,52-53 \mathrm{~cm}$. 7. Eouvigerina hispida Cushman $(50 \mu \mathrm{m})$, Sample $585-20-3,52-53 \mathrm{~cm}$. 8-9. Stilostomella pseudoscripta (Cushman) (100 $\mu \mathrm{m})$, (8) Sample $585-18-2,23-$ $27, \mathrm{~cm}$, (9) Sample 585-20-3, 52-53 cm. 10-12. Reussella szajnochae (Grzybowski) $(80 \mu \mathrm{m})$, Sample 585-18-2, 23-27 cm, (10-11) side and apertural views, (12) side view. 13, 18, 23. Valvulineria lenticula (Reuss), spiral, edge, and umbilical views (70 $\mu \mathrm{m})$, Sample 585-20-3, 52-53 cm. 14-16. Conorbina sp. cf. C. marginata Brotzen, spiral, edge, and umbilical views ( $40 \mu \mathrm{m})$, Sample 585-29-2, 46-48 cm. 17, 22. Pseudopatellinella minuta Sliter, spiral and umbilical views $(50 \mu \mathrm{m})$, Sample $585-20-3,52-53 \mathrm{~cm} . \quad 19-21$. Serovaina orbicella (Bandy), spiral, edge, and umbilical views $(50 \mu \mathrm{m})$, Sample $585-20-3,52-53 \mathrm{~cm}$. 


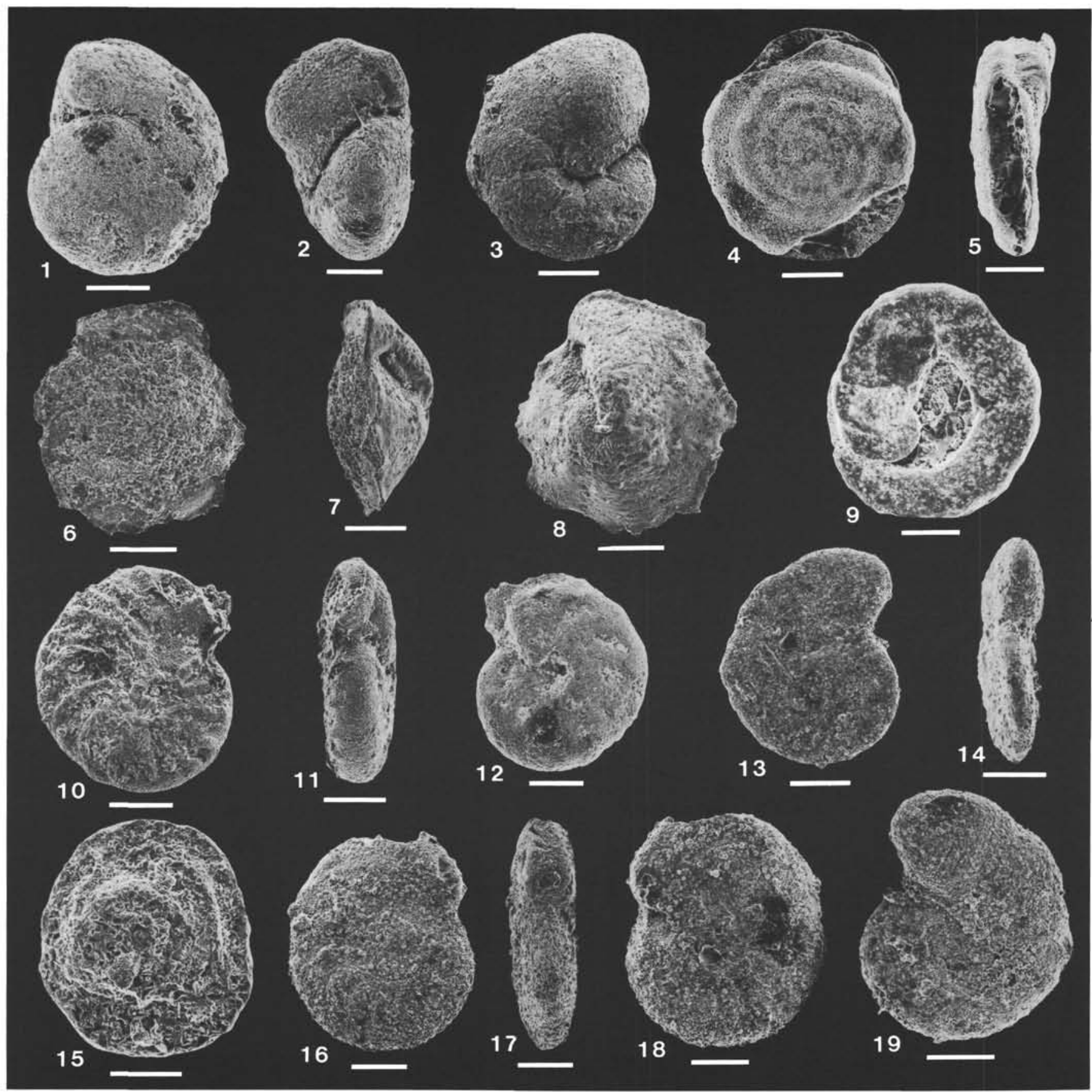

Plate 7. 1-3. Valvulineria loetterle (Tappan), spiral, edge, and umbilical views (60 $\mu \mathrm{m})$, Sample 585A-9-1, 64-72 cm. 4-5, 9. Conicospirillina sp., spiral, edge, and umbilical views ( $50 \mu \mathrm{m}$ ), Sample 585A-11-5, $43-45 \mathrm{~cm}$. 6-8. Nuttallinella florealis (White), spiral, edge, and umbilical views $(80 \mu \mathrm{m})$, Sample 585-20-3, 52-53 cm. 10-12, 16-18. Planulina lundegreni Brotzen, spiral, edge, and umbilical views (70 $\mu \mathrm{m})$, (10-12) Sample 585A-9-1, 32-34 cm, (16-18) Sample 585-32-4, 97-99 cm. 13-14, 19. Planulina sp., spiral, edge, and umbilical views (70 $\mu \mathrm{m})$, Sample 585-32-4, $97-99 \mathrm{~cm}$. 15. Patellina subcretacea Cushman and Alexander, spiral view $(40 \mu \mathrm{m})$, Sample $585-20-3,52-53 \mathrm{~cm}$. 


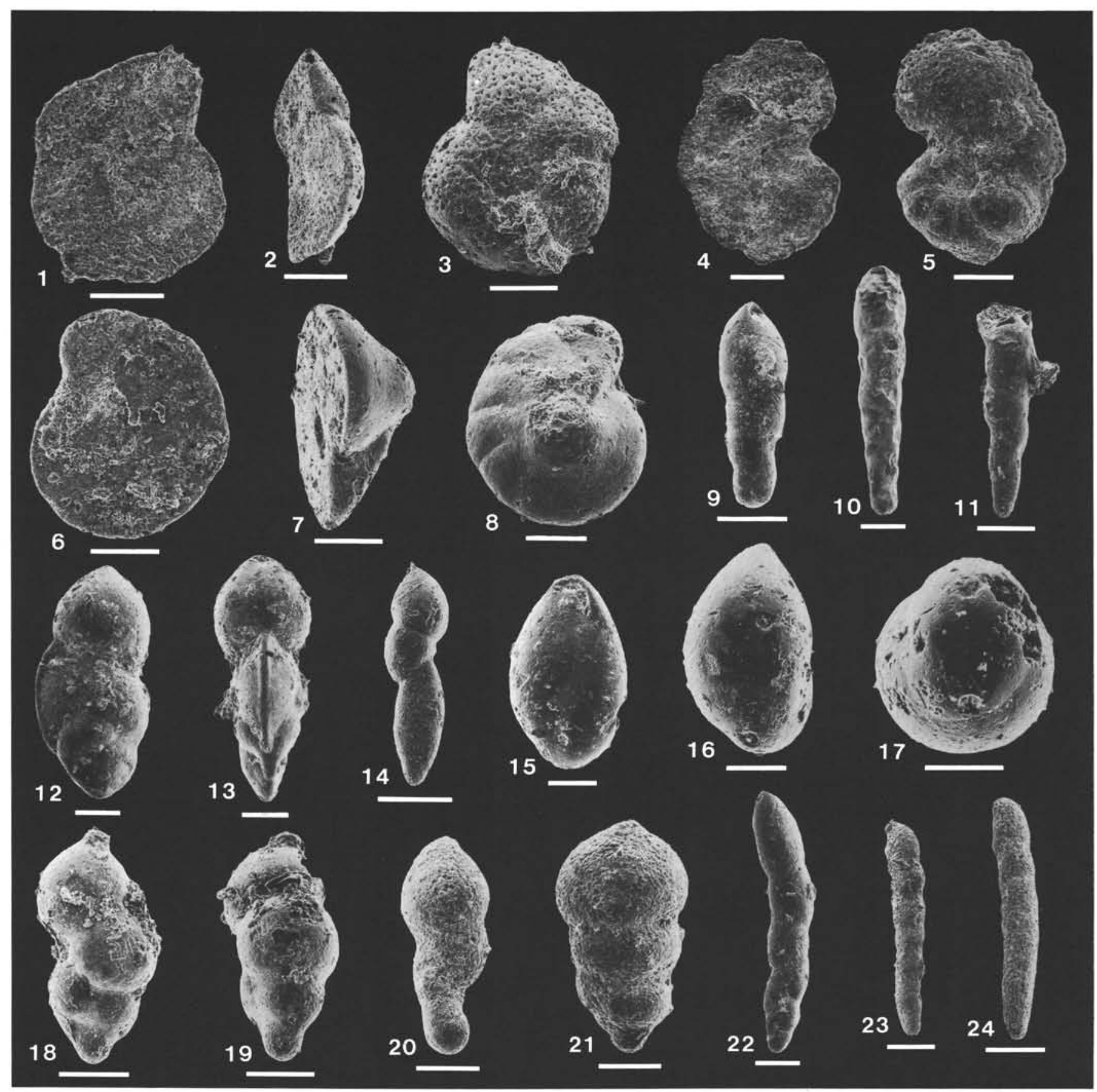

Plate 8. 1-5. Cibicides ribbingi Brotzen $(80 \mu \mathrm{m})$, Sample 585-20-3, 52-53 cm, (1-3) opposite side and edge views of small specimen, (4-5) opposite side views of large specimen. 6-8. Cibicides voltziana (d'Orbigny), opposite side and edge views (70 $\mu \mathrm{m}$ ), Sample 585-20-3, 52-53 cm. 910. Pleurostomella obtusa Berthelin $(150 \mu \mathrm{m})$, (9) Sample 585-32-4, 97-99 cm, (10) Sample 585-42,CC (13-15 cm). 11. Pleurostomella subnodosa Reuss, broken specimen $(150 \mu \mathrm{m})$, Sample $585-20-3,52-53 \mathrm{~cm}$. 12-13. Ellipsodimorphina sp. 1, side and edge views (100 $\mu \mathrm{m})$, Sample 585-20-3, 52-53 cm. 14. Ellipsodimorphina sp. $2(100 \mu \mathrm{m})$, Sample 585-18-2, 23-27 cm. 15-17. Pleurostomella zuberi Gryzbowski, face, side and apical views $(70 \mu \mathrm{m})$, Sample 585-18-2, 23-27 cm. 18-20. Ellipsoidella coalingensis (Cushman and Church) $(80 \mu \mathrm{m}),(18-19)$ side and face views of a large specimen, Sample 585-18-2, 23-27 cm, (20) side view of small specimen, Sample 585-20-3, 52-53 cm. 21 . Ellipsoidella kugleri (Cushman and Renz) $(80 \mu \mathrm{m})$, Sample $585-20-3,52-53 \mathrm{~cm}$. 22. Ellipsoidella gracillima (Cushman) $(100 \mu \mathrm{m})$, Sample $585-20-3,52-53 \mathrm{~cm}$. 2324. Ellipsoidella sp. $(80 \mu \mathrm{m})$, Sample $585-20-3,52-53 \mathrm{~cm}$. 


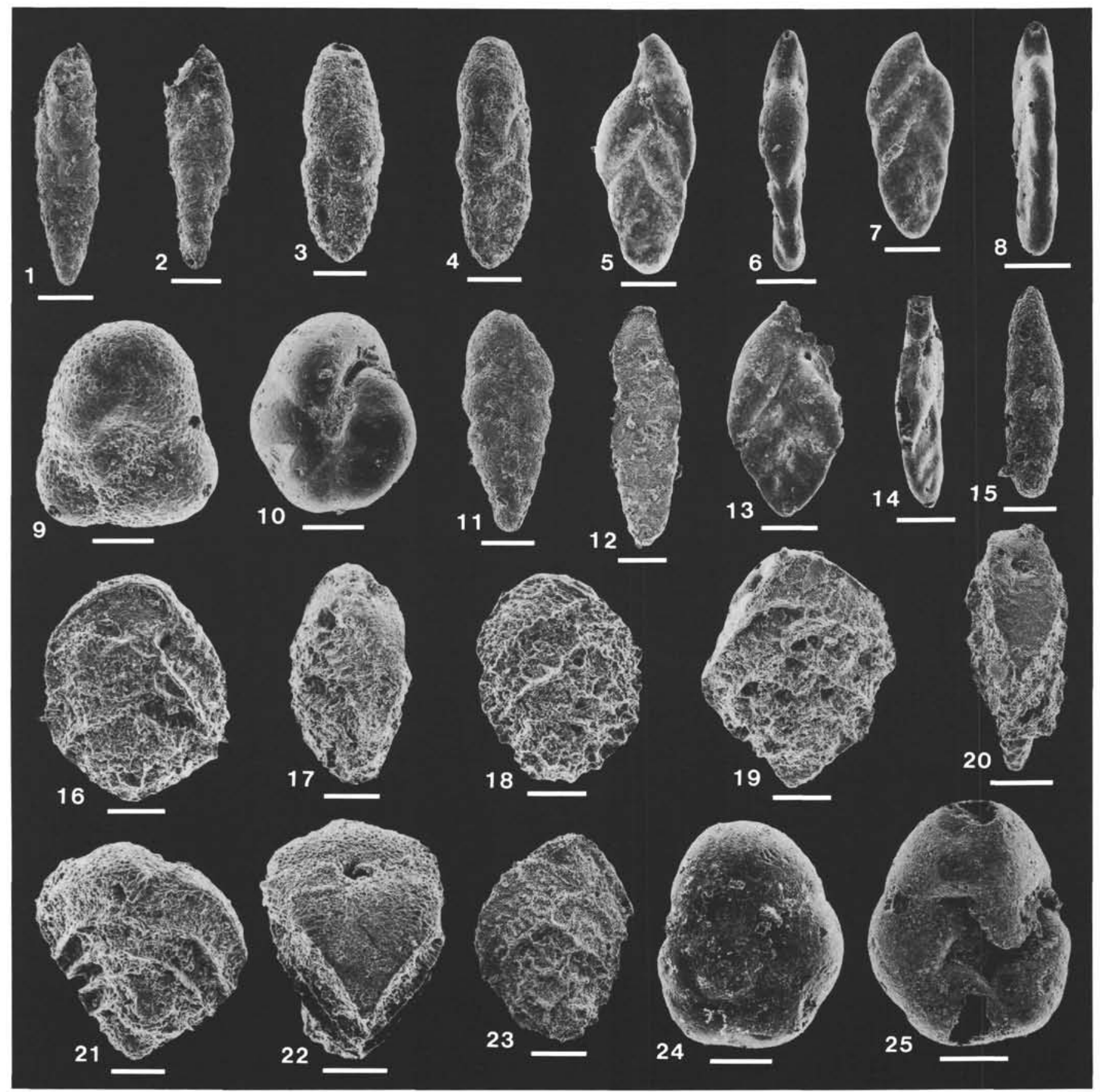

Plate 9. 1-2. Fursenkoina nederi Sliter $(80 \mu \mathrm{m})$, edge and side views, Sample 585-18-2, 23-27 cm. 3-4. Coryphostoma sp. cf. C. minutissimum (Cushman) $(60 \mu \mathrm{m})$, (3) Sample 585-32-3, 24-27 cm, (4) Sample 585-29-2, 46-48 cm. 5-8. Coryphostoma reussi (Geinitz) $(70 \mu \mathrm{m})$, Sample 58520-3, 52-53 cm, (5-6) side and edge views, (7-8) side and edge views. 9. Allomorphina halli Jennings, umbilical view (50 $\mu \mathrm{m})$, Sample 585-20-3, $52-53 \mathrm{~cm}$. 10. Pullenia minuta Cushman $(100 \mu \mathrm{m})$, Sample $585-20-3,52-53 \mathrm{~cm}$. 11. Cassidella tegulata (Reuss) $(80 \mu \mathrm{m})$, Sample $585-20-3$, $52-53 \mathrm{~cm}$. 12. Loxostomum eleyi (Cushman) $(80 \mu \mathrm{m})$, Sample 585-20-3, 52-53 cm. 13-14. Coryphostoma sp., side and edge views $(80 \mu \mathrm{m})$, Sample 585-20-3, 52-53 cm. 15. Coryphostoma plaitum (Carsey) $(50 \mu \mathrm{m})$, Sample 585-20-3, 52-53 cm. 16-18, 23. Aragonia velascoensis (Cushman) $(60 \mu \mathrm{m}),(16-17)$ side and edge views, Sample 585-20-3, 52-53 cm, (18) Sample 585-20-3, 52-53 cm, (23) Sample 585-18-2, 23$27 \mathrm{~cm}$. 19-20. Aragonia trinitatensis (Cushman and Jarvis), side and oblique edge views (70 $\mu \mathrm{m})$, Sample 585-20-3, 52-53 cm. 21-22. Aragonia ouezzanensis (Rey), side and oblique edge views $(50 \mu \mathrm{m})$, Sample $585-20-3,52-53 \mathrm{~cm}$. 24-25. Quadrimorphina allomorphinoides (Reuss), spiral and umbilical views $(70 \mu \mathrm{m})$, Sample $585-32-4,97-99 \mathrm{~cm}$. 


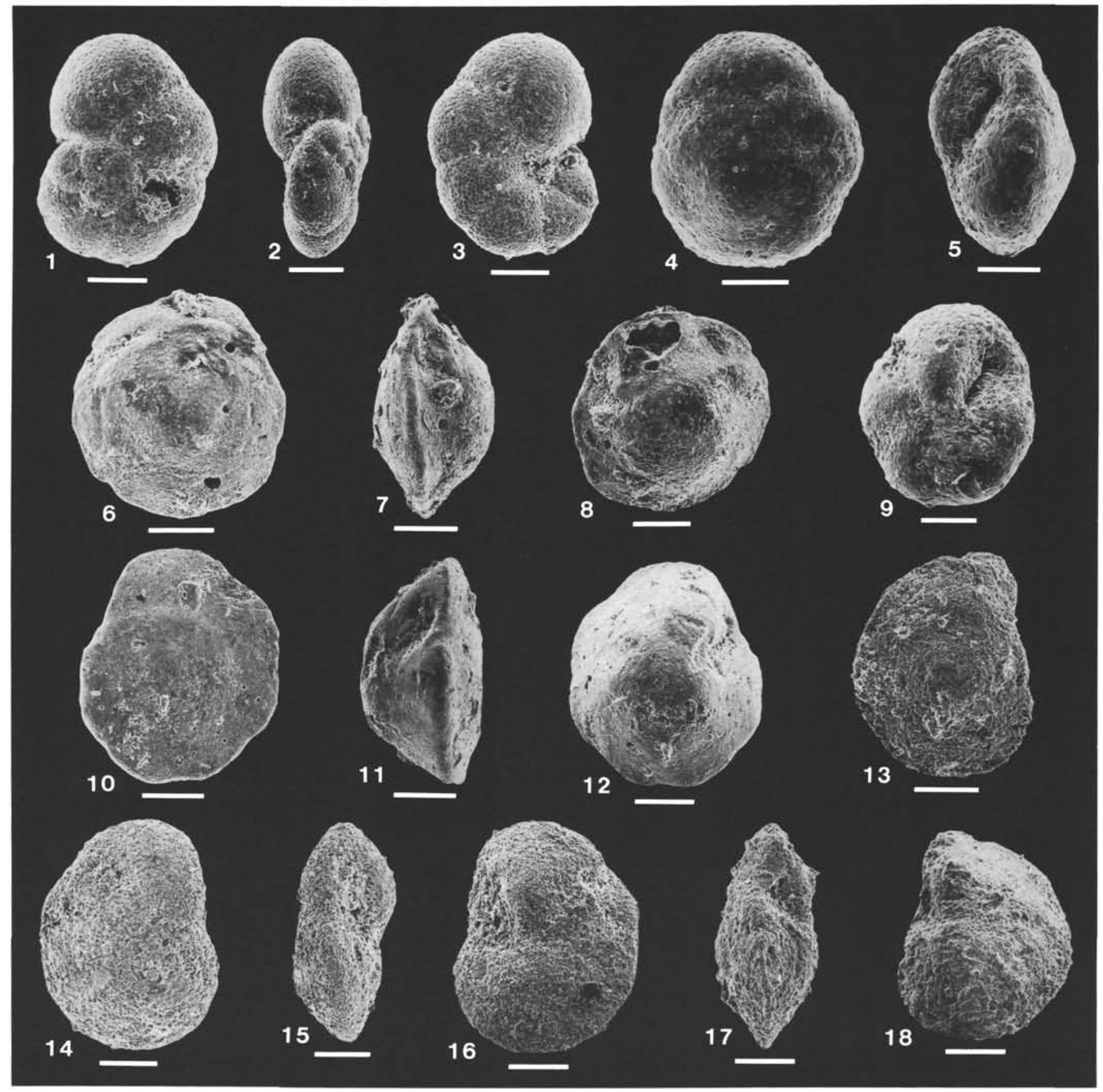

Plate 10. 1-3. Nonionella robusta Plummer, spiral, edge, and umbilical views, $(40 \mu \mathrm{m})$, Sample 585-18-2, 23-27 cm. 4-5, 9. Alabamina dorsoplana (Brotzen), spiral, edge, and umbilical views $(50 \mu \mathrm{m})$, Sample 585-20-3, 52-53 cm. 6-8, 10-12. Osangularia cordieriana (d'Orbigny), spiral, edge, and umbilical views $(70 \mu \mathrm{m})$, Sample 585-20-3, 52-53 cm, (6-8) typical morphology; (10-12) less common plano-convex morphology. 13, 17-18. Osangularia navarroana (Cushman), spiral, edge, and umbilical views $(60 \mu \mathrm{m})$, Sample $585-20-3,52-53 \mathrm{~cm}$. 14-16. Osangularia schloenbachi (Reuss), spiral, edge, and umbilical views $(60 \mu \mathrm{m})$, Sample 585A-9-1, 32-34 cm. 


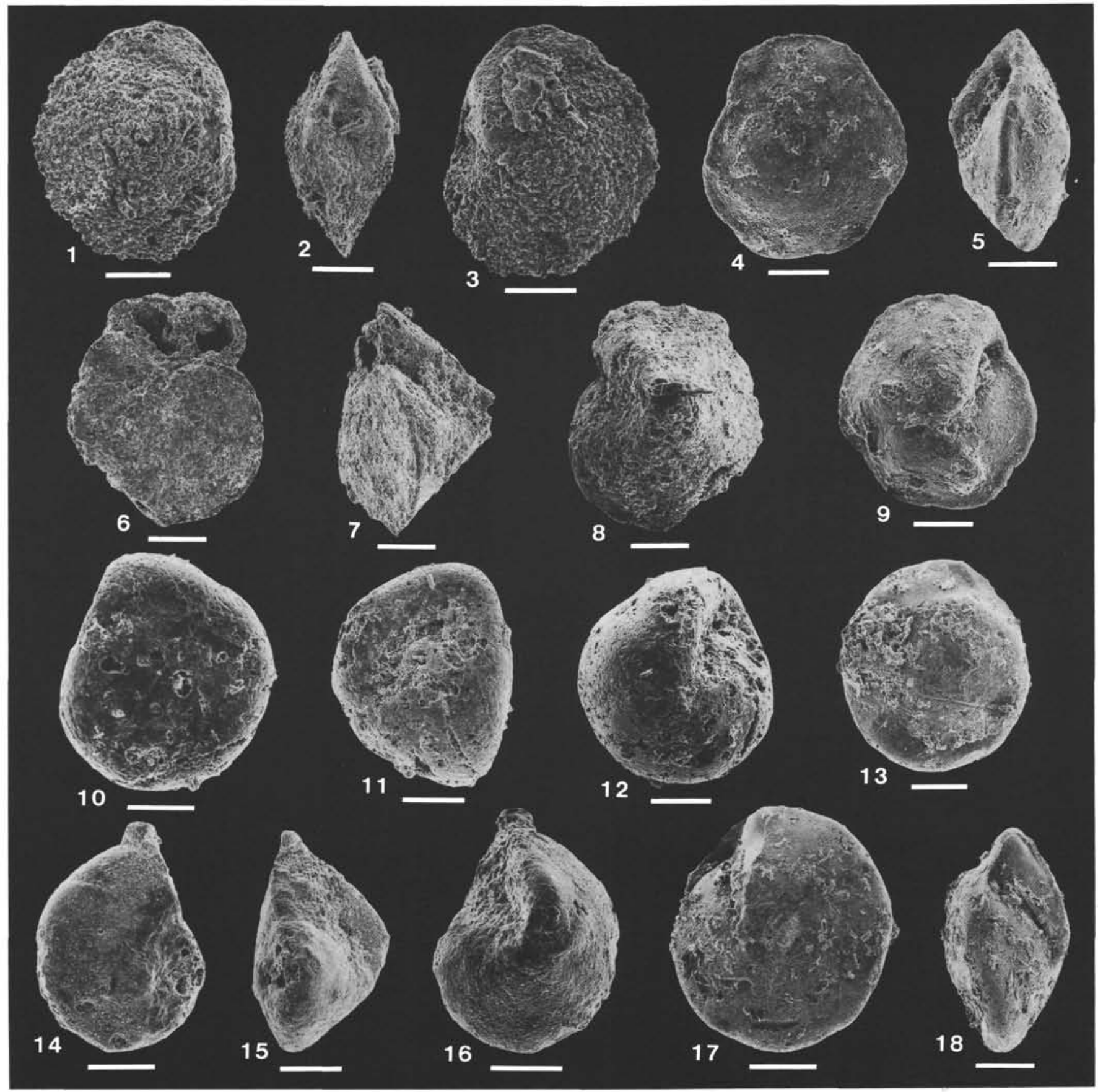

Plate 11. 1-3. Osangularia whitei (Brotzen), spiral, edge, and umbilical views $(70 \mu \mathrm{m})$, Sample 585-32-4, 97-99 cm. 4-5, 9. Charltonina sp. cf. C. meeterenae (Visser), spiral, edge, and umbilical views $(70 \mu \mathrm{m})$, Sample $585-20-3,52-53 \mathrm{~cm}$. 6-8. Globorotalites michelianus (d'Orbigny), spiral, edge, and umbilical views $(80 \mu \mathrm{m})$, Sample $585-20-3,52-53 \mathrm{~cm}$. 10-12. Globorotalites tappanae Sliter, spiral, edge, and umbilical views, $(60 \mu \mathrm{m})$, Sample 585-20-3, 52-53 cm. 13, 17-18. Gyroidinoides beisseli (Schijfsma), spiral, umbilical, and edge views $(60 \mu \mathrm{m})$, Sample $585-$ 20-3, 52-53 cm. 14-16. Globorotalites sp., spiral, edge, and umbilical views $(70 \mu \mathrm{m})$, Sample 585-51-3, $54-56 \mathrm{~cm}$. 


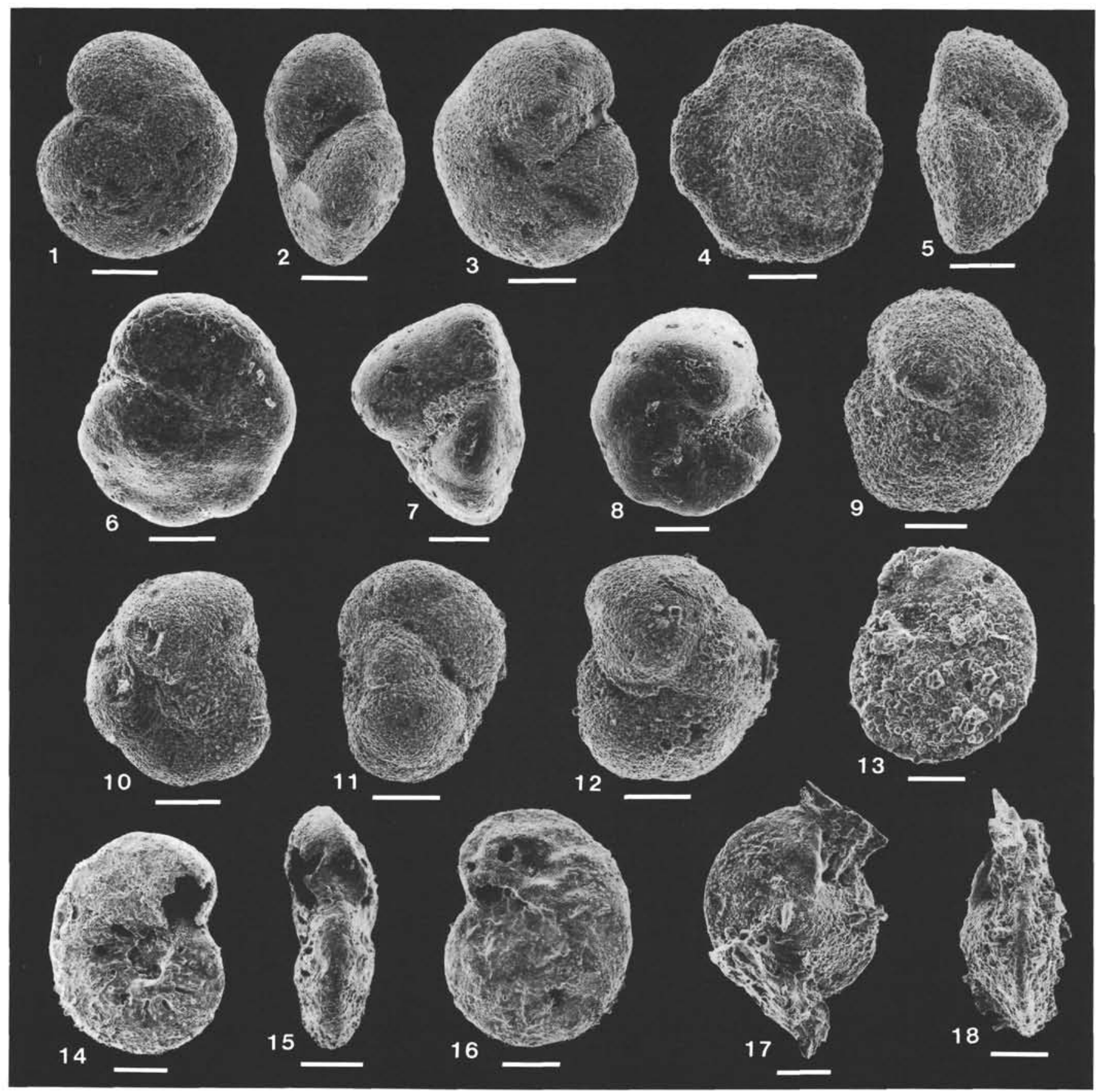

Plate 12. 1-3. Gyroidinoides infracretaceus (Morozova), spiral, edge, and umbilical views $(70 \mu \mathrm{m})$, Sample $585-32-4,97-99 \mathrm{~cm}$. 4-5, 9. Gyroidinoides megastomus (Grzybowski), spiral, edge, and umbilical views ( $70 \mu \mathrm{m})$, Sample 585-20-1, 17-19 cm. 6-8. Gyroidinoides nitidus (Reuss), spiral, edge, and umbilical views $(50 \mu \mathrm{m})$, Sample 585-20-3, 52-53 cm. 10-12. Gyroidinoides subglobosus Dailey, spiral, edge, and umbilical views $(70 \mu \mathrm{m})$, Sample $585-32-4,97-99 \mathrm{~cm} .13,17-18$. Gavelinella belorussica (Akimez), spiral, umbilical, and edge views, $(60 \mu \mathrm{m})$, Sample 585-32-3, 24-27 cm. 14-16. Gavelinella barremiana bizouardae Maync $(70 \mu \mathrm{m})$, Sample 585-42,CC (13-15 cm), (14-15) umbilical and edge views, (16) umbilical view. 


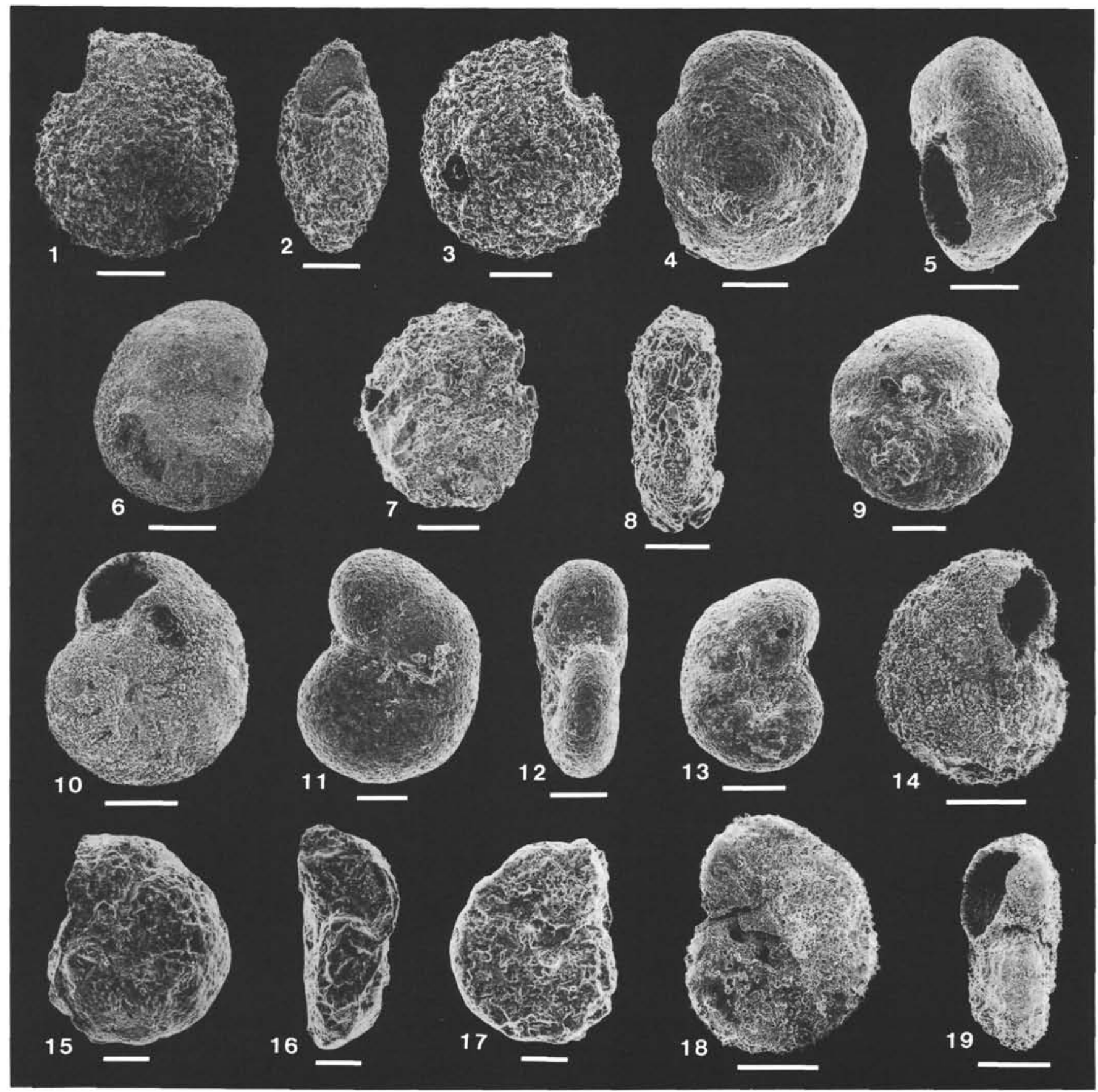

Plate 13. 1-3. Gavelinella sp. cf. G. bembix (Marsson), spiral, edge, and umbilical views (70 $\mu \mathrm{m})$, Sample 585-29-2, 46-48 cm. 4-5, 9. Gavelinella cayeuxi mangshalakensis (Vassilenko) $(60 \mu \mathrm{m})$, Sample 585-20-3, 52-53 cm, (4-5) spiral and edge views; (9) umbilical view of second specimen. 6, 10. Gavelinella intermedia (Berthelin), spiral and umbilical views $(100 \mu \mathrm{m})$, Sample $585-42, \mathrm{CC}(13-15 \mathrm{~cm})$. 7-8. Gavelinella cenomanica (Brotzen), spiral and edge views $(100 \mu \mathrm{m})$, Sample 585-41,CC. 11-13. Gavelinella nacatochensis (Cushman), spiral, edge, and umbilical views $(50 \mu \mathrm{m})$, Sample 585-20-3, 52-53 cm. 14-19. Gavelinella rudis (Reuss) $(80 \mu \mathrm{m}),(14,18-19)$ spiral, umbilical, and edge views, Sample 585$42, \mathrm{CC}(13-15 \mathrm{~cm}),(15-17)$ spiral, edge, and umbilical views, Sample 585-41,CC. 


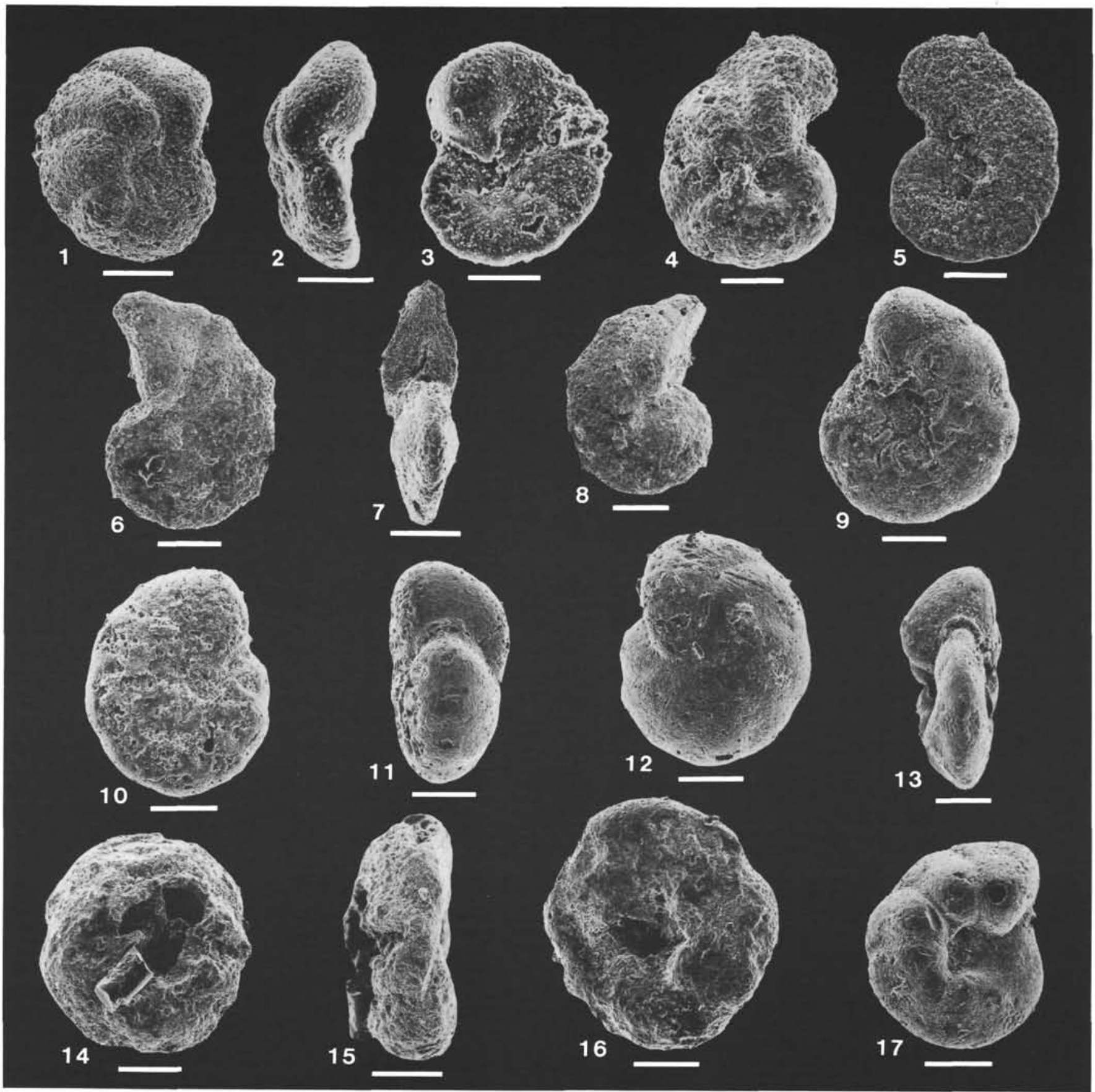

Plate 14. 1-5. Gavelinella sandidgei (Brotzen) $(70 \mu \mathrm{m})$, Sample 585-32-3, 24-27 cm, (1-3) spiral, edge, and umbilical views, (4-5) spiral and umbilical view. 6-8. Gavelinella sp., spiral, edge, and umbilical views $(80 \mu \mathrm{m})$, Sample 585-20-3, 52-53. 9, 13, 17. Orithostella pazdroae (GaworBeidowa), spiral, edge, and umbilical views $(70 \mu \mathrm{m})$, Sample 585-32-4, 97-99 cm. 10-12. Gavelinella whitei (Martin), spiral, edge, and umbilical views $(60 \mu \mathrm{m})$, Sample $585-20-3,52-53 \mathrm{~cm}$. 14-16. Conorboides sp., spiral, edge, and umbilical views $(80 \mu \mathrm{m})$, Sample $585-51-3,54-56 \mathrm{~cm}$. 


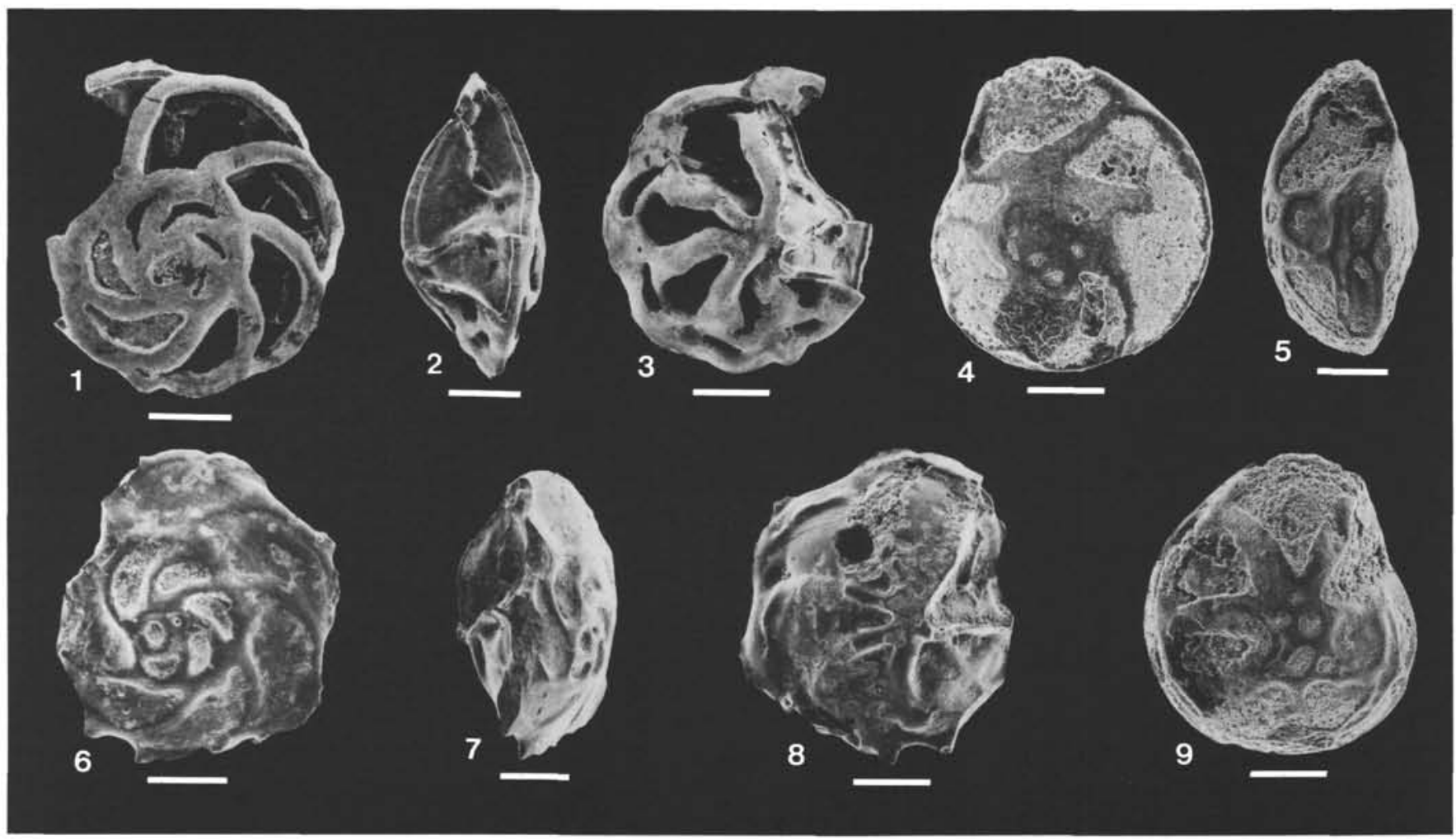

Plate 15. 1-3. Epistomina chapmani ten Dam, spiral, edge, and umbilical views (200 $\mu \mathrm{m})$, Sample 585A-11-5, 43-45 cm. 4-5, 9. Epistomina reticulata (Reuss), spiral, edge, and umbilical views $(70 \mu \mathrm{m})$, Sample $585 \mathrm{~A}-11-2,96-99 \mathrm{~cm} . \quad 6-8$. Epistomina spinulifera (Reuss), spiral, edge, and umbilical views $(200 \mu \mathrm{m})$, Sample $585 \mathrm{~A}-11-2,96-99 \mathrm{~cm}$. 